Tér és Társadalom 11. évf. 1997/1. 219-269. p.

\title{
AZ ÉSZAKNYUGAT-DUNÁNTÚL TERÜLETFEJLESZTÉSI STRATÉGIÁJA (TERVEZET)
}

(Regional Development Strategy of North-West Transdanubia)

\section{LADOS MIHÁLY - RECHNITZER JÁNOS}

\section{Elözmények és feltételek}

A Környezetvédelmi és Területfejlesztési Minisztérium (KTM) 1995. januárjában megbizta az MTA Regionális Kutatások Központja Nyugat-magyarországi Tudományos Intézetét (NYUTI), hogy dolgozza ki az Északnyugat-Dunántúl négy megyéjére (Györ-Moson-Sopron, Vas, Veszprém és Zala megye), mint együttes régiónak tekinthető térségre' az egységesen értelmezhetỏ területfejlesztési koncepcióját.

A területfejlesztési koncepció elkészitését a következők indokolták:

- az ország több nagytérségében (Alföld, Dél-Dunántúl) kidolgozásra kerültek a regionális dimenzióban értelmezhetō teriületfejlesztési koncepciók, megkezdödött tehát a regionális tervezés új szemléletủ módszereinek elemzése, azok több régióban való alkalmazása,

- az Északnyugat-Dunántúl három megyéje (Győr-Moson-Sopron, Vas, Zala) 1995-ben bekapcsolódhatott az INTERREG II.-Phare CBC programba, amelynek célja az osztrák-magyar határ menti térségek együttműködésének sokirányú erősítése, szükséges tehát, hogy a térségre egységes szemléletet követö területfejlesztési koncepció kerüljön kidolgozásra,

- a regionális együttmüködés jegyei egyre határozottabban felismerhetók voltak az elmúlt években, részben a fentebb nevezett program elókészítése során, részben pedig a határ menti kapcsolatok élénkülése következtében, annak különféle intézményeinek létrejöttével (Hatánnenti Regionális Tanács 1992-től),

- az Északnyugat-Dunántúl megyéi felismerték, hogy a térségi társadalmigazdasági fejlesztés jelentősége a kilencvenes évek közepétől növekedni fog, így 1994-től megkezdödött a megyei szintü fejlesztési koncepciók kidolgozása, ezen fejlesztési stratégiák elkészültek, s lehetöség kínálkozott az egységes tervezési elvek és módszerek alkalmazására, a regionális és a megyei szintek összekapcsolására,

- az Északnyugat-Dunántíl gazdasági szempontból is felértékelödött, szükséges volt tehát rendszerezni a térség eröforrásait, összegezni a rendelkezésre álló adottságokat, áttekinteni a fejlesztési 
kezdeményezéseket, s meghatározni azokat az irányokat, amelyek a jövőben a térség folyamatait alakítják, illetve meghatározni, hogy a különféle szereplök kezdeményezéseit milyen irányba célszerü terelni,

- az elfogadásra került Törvény a területfejlesztésról és rendezésröl (1996. évi XXI. törvény), lehetőséget ad a regionális területfejlesztési tanácsok létrehozására, hogy a szomszédos és az egymással kapcsolatban lévő megyékben a nagyobb térséget érintő gazdasági, infrastrukturális, településhálózati és társadalmi, környezeti kérdéseket az érintettek együttesen kezeljék, egy jövőbeli regionális tervezési és elemzési (statisztikai) egységek megteremtése érdekében,

- elkészült és a Kormány, illetve az Országgyúlés elé kerül az Országos Területfejlesztési Koncepció (OTK), amely meghatározza a területi szerkezet alakításának fóbb szempontjait és irảnyait, a regionális koncepcióban érvényesíteni kell az ország egészére, illetve azon belül a térségre értelmezhetö fejlesztési elveket és célokat, ugyanakkor a térségre vonatkozó fejlesztési irányokat meg kell jeleníteni az országos koncepcióban.

A térségre kidolgozásra került területfejlesztési koncepció alapelveit a következö feltételek befolyásolják:

- az európai regionális folyamatok irányai:

$\Rightarrow$ a dezindusztrializáció (az ipar fokozatos térvesztése),

$\Rightarrow$ a tercierizáció (a szolgáltatóipar gyors túlsúlyba kerülése a gyáriparral szemben),

$\Rightarrow$ a technológiai váltás (tudásiparok, képzettség, új technológiák alkalmazása),

$\Rightarrow \quad$ a decentralizáció (helyi döntések szerepe, verseny az erőforrásokért),

$\Rightarrow$ a fenntartható fejlödés követelményei (a gazdasági növekedés és a környezetterhelés összekapcsolása),

- a területfejlesztés országos céljai:

$\Rightarrow \quad$ a társadalmi-gazdasági helyzetek és esélyek közelitése (a társadalmi szolidaritás és a területi kohézió erősítése, egységes alapellátás megteremtése),

$\Rightarrow$ hozzájárulás az ország gyorsabb és hatékonyabb fejlödéséhez (nemcsak az elmaradott térségek felzárkóztatása, hanem a fejlettebb térségek adottságainak jobb kihasználása),

$\Rightarrow$ fenntartható fejlödés és a környezeti potenciállal összhangban lévó területi szerkezet kialakítása (térségek, települések környezeti állapotának megóvása, helyi és térségi adottságok figyelembe vétele),

$\Rightarrow \quad a z E U$ csatlakozás területfejlesztési követelményeinek érvényesitése (fejlesztési alapok hatékony fogadási feltételeinek biztosítása), 
- az Európai Unió regionális politikájának alapelvei:

$\Rightarrow$ szubszidiaritás és decentralizáció (önálló mozgástér, döntési kompetencia, erőforrások feletti rendelkezés),

$\Rightarrow$ partnerség (a területfejlesztés szereplöinek együttmüködése),

$\Rightarrow$ programozás (alulról építkező stratégiák, fejlesztési prioritások, programok),

$\Rightarrow \quad$ koncentráció és addicionalitás (jól elhatárolható területi fejlesztési típusok, kombinált költségvetés),

- az országhatáron túli, a térség gazdaságával szoros kapcsolatban lévő külföldi régiók (országok) fejlödési irányai,

- a szomszédos és a gazdasági kapcsolatokban domináns hazai régiók, centrumok fejlődési irányai, azoknak a térségre gyakorolt hatása,

- a térség és azt alkotó megyék helye és szerepe a hazai modernizációban,

- a térségre, annak megyéire rendelkezésre álló fejlesztési koncepciók és programok,

- a települések, térségek és a gazdasági szereplök jövőképe, azok elvárásai a térség fejlödésével szemben.

\section{A területfejlesztési stratégia tartalma}

\section{CÉL}

A térség fejlödését hosszú (6-10 év), közép (3-5 év) és rövid távon (1-2 év) meghatározó tényezők feltárása, mindezek alapján a fejlesztés lehetséges változatainak kidolgozása, azokhoz rendelhetö prioritások (fejlesztési célok, s azokhoz kapcsolódó egyes programok jellegének) kijelölése, s a megvalósításuk eszköz-és intézményrendszereinek meghatározása.

A területfejlesztési stratégia keret-jellegü cselekvési programcsomag, amely a térség fejlesztésének legfontosabb irányait tartalmazza, igy az egyes megyék, kistérségek és települések, de a különféle területfejlesztési szereplök is, ehhez rendelhetik és kapcsolhatják saját fejlesztési koncepciójukat.

\section{FELÉPÍTÉS (1. ÁBRA)}

- Felvázolja és értékeli a térségben zajló fontosabb népességi, környezeti, infrastrukturális, gazdasági, településhálózati, társadalmi, kulturális folyamatokat, meghatározza azok erősségeit és gyengeségeit,

- áttekinti a térség egészét, $s$ annak föbb szereplöit érintő nemzetközi (keletközép-európai) hatásokat, értékeli a térség versenyhelyzetét a hazai térszerkezetben, teszteli a területfejlesztés szereplöinek véleményét a térség adottságai és fejlesztési irányairól, s megállapítja a mindezekben rejlö, jövőbeli lehetőségeket és veszélyeket,

- mindezek alapján kijelöli a fejlődés lehetséges forgatókönyveit, elemzi azok hatását és következményeit, ajánlatot tesz a legkedvezőbb jövőképre, 


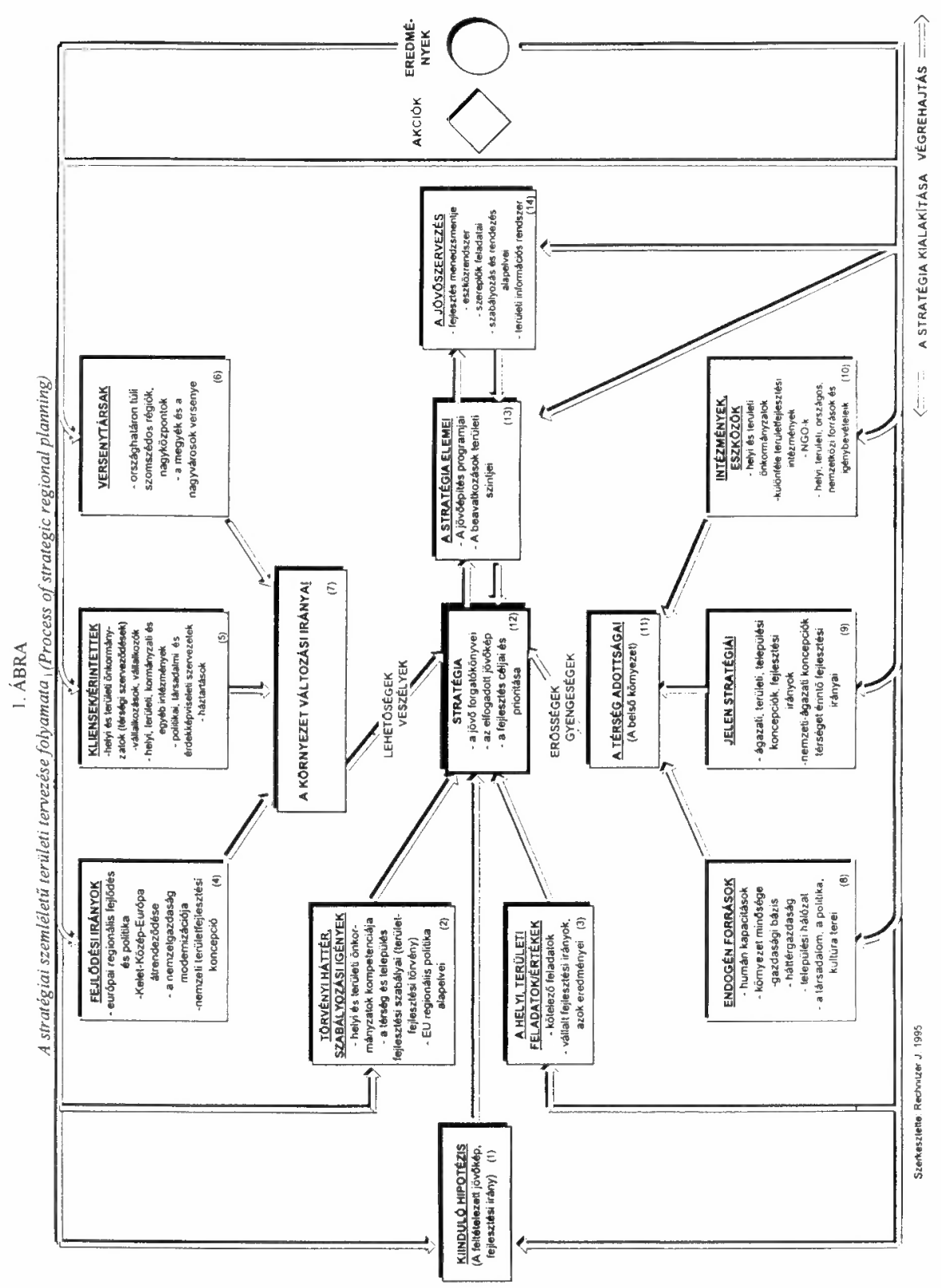


Tér és Társadalom, 11. 1997. 1. 219-269. p.

- meghatározza a legkedvezöbb jövőképhez rendelt célrendszert, kijelöli a részcélok tartalmát, felvázolja az azokhoz kapcsolódó programok föbb tartalmi elemeit,

- meghatározza a fejlesztés beavatkozási térségeit, azokhoz rendeli a célokat és programokat,

- meghatározza a célok és programok finanszírozási hátterét, s kijelöli azok megvalósításának intézményeit,

- $\quad$ s végül kijelöli a megvalósitást értékelő rendszer müködési elveit.

\section{JELLEG}

Az alternatív gondolkodás, ami a fejlesztés különféle szemléletben (polarizált, közepesen koncentrált, dekoncentrált) készült változatai alapján tesz javaslatot a fejlesztés lehetséges - legkedvezőbb - irányára, annak célrendszerére, azok megvalósítására szolgáló eszköz- és intézményrendszer kidolgozására.

\section{A FEJLÖDÉSI IRÁNY MEGHATÁROZÁSA}

A térség fejlödésének egyes forgatókönyveihez alapot a nemzeti regionális fejlödés lehetséges modelljei szolgáltatták. Ezt adaptáltuk a térségre, keresve egyben a sajátosságokat, a különbségeket, az egyedi jövöképet formáló tényezőket. A "legkedvezőbb" jövőkép kiválasztása három irányból következett.

A) Az egyik irány a megyék jövóképe, azok lehetséges és egyben elfogadott fejlesztési stratégiája, hiszen ezek legalizálása megtörtént a megyei önkormányzatok és a megyei területfejlesztési tanácsok szintjén.

B) A másik irány a térségnek, mint potenciális régiónak a sajátosságai, azok az egyediségek, amelyek a regionális folyamatokat erösítik, egyben túlmutatnak a megyei sajátosságokon, itt és csak is benne a térségben értelmezhetök, s mint jövöbeli regionális funkciók hordozói.

C) A harmadik irány $a z$ OTK, amelyben a kijelölt fejlesztési célok alapján értelmezzük a térségi - regionális - erőforrásokat és adottságokat, s az országos jövőkép regionális megfelelöit határozzuk meg.

A három irány eredöjeként kerül meghatározásra a térség lehetséges fejlesztési koncepciója, hangsúlyozottan azon célokra, amelyek

$\square \quad$ a megyei fejlesztésekben térségi - regionális - jelentöséggel rendelkeznek,

\a térség egészének sajátosságaiból következnek, annak már lehetséges regionális - a megyéket együttesen kezeló - meghatározottságait tartalmazzák,

\az országos területi fejlödésnek a térségi szintü értelmezéséböl következnek. 


\section{ÉRINTETTEK}

$\mathrm{Az}$ ágazati minisztériumok, a különféle kormányzati szervek, a regionális fejlesztési tanács, a megyei területfejlesztési tanácsok, területi és helyi önkormányzatok, a gazdasági szervezetek, azok szakmai képviseletei, a térségben található nem önkormányzati költségvetési intézmények, a társadalmi és non-profit szervezetek és az elóbbieken keresztül a lakosságot is megtestesító háztartások.

\section{IDÖNTERVALLUM}

A stratégia a hosszú távú fejlődési folyamatok irányainak kijelölése az ezredforduló utánig (6-10 esztendő), miközben információt nyújt a közép (3-5 év) és rövid távú (1-2 év) beavatkozások lehetséges hatásainak számbavételére, illetve a fejlesztés prioritásait érintő különféle döntések mérlegelésére. Szükséges kétévente áttekinteni a területfejlesztési stratégiában foglaltak megvalósulását, illetve az OTK időszaki értékelésével és a megyei területfejlesztési koncepciók megújitásával együtt elemezni és áttekinteni, szükségszerủen módosítani a térségi területfejlesztési stratégiát. ${ }^{2}$

A stratégia

\section{MEGVALÓSÍTÁS}

$\Rightarrow \quad$ tartalmazza a végrehajtás feltételeit,

$\Rightarrow$ meghatározza a fejlesztéshez rendelhetö eszközöket (források felvázolása) és intézményeket (fejlesztés menedzsmentje és a különféle szereplők feladatai), valamint

$\Rightarrow$ kijelöli az értékelési és visszajelzési rendszer föbb elemeit (területi információs rendszer).

\section{ELFOGADÁS, ÉRVÉNYESSÉG}

A térség (régió) területfejlesztési stratégiáját a törvény értelmében a Kormány fogadja el, a megyei és a regionális területfejlesztési tanácsok véleményének kikérésével, mely az elfogadás után nyeri el érvényességét.

\section{A térség fejlesztési stratégiájának épitökövei}

Az Északnyugat-Dunántúl jövőképének kidolgozásánál a stratégia tervezés klasszikus eszközével élve, a swot-analízissel hipotetikusan számba kell venni a régió belső adottságainak gyengeségeit és erősségeit, illetve a külsỏ tényezőkben rejlő lehetöségeket és veszélyeket, majd ezek alapjản felvázolni a régió jövőjét meghatározó fejlesztési irányokat. 


\subsection{A térség adottságai: erösségek}

- A térség népességének az országos átlagnál magasabb a gazdasági aktivitása, az iskolázottsági szintje, valamint kedvezőbb a nyelvismerete. Az ÉszaknyugatDunántúl az ország innovatívabb, nagyobb tudással és tapasztalattal rendelkezỏ népességét fogadia be, az elvándorlás mérsékelt, így a népességfogyás tendenciája az országos viszonyoknál valamivel kedvezöbb. Hosszú távon Györ-Moson-Sopron és Veszprém megye demográfiai helyzete viszonylag kiegyensúlyozott (a népességfogyás 7-8\% közötti lesz), mig Vas és Zala megyében, illetve nagyvárosaikban a népesség számának csökkenése meghaladja az országos mértéket $(12-13 \%)$.

- Magas iparosodottsági szint, amely jelentös teljesítóképességet produkál, a számottevó export - szinte minden ágazatban és jelentösebb centrumban - a gazdasági egységek külpiaci kapcsolatainak sokoldalúságát mutatja. Az ipar ágazati szerkezete heterogén, de a gazdasági klaszterek csírái már megjelentek: gépipar és autógyártás; Gyôr, Szombathely, Szentgotthárd, elektronikai ipar; Szombathely, Nagykanizsa, építőanyag-ipar, faipar, bútoripar és lakásfelszerelések gyártása; Veszprém, Sopron, Győr, Szombathely, Zalaegerszeg, Nagykanizsa, vegyipar; Veszprém, Zalaegerszeg, élelmiszeripar; Győr, Veszprém. A térségben számottevő kis- és középvállalkozás szerveződött, ezekből ugyan még kevés tudott felfüződni a nagyvállalatokra, beszállítási kapcsolatokat kialakítani, de már vannak kezdeményezések részben az önálló arculatra, részben a szervezett együttmüködésekre.

- A külföldi tỏke több jelentős beruházása a térségben található, illetve a privatizáció során nemzetközi nagyvállalatok szereztek számottevő tulajdont. Emellett fóleg Ausztriából nagyszámú kis és közepes befektetés jelent meg a térségben, amelyek a gazdaság széles körét fogják át. A külgazdasági kapcsolatok az ÉszaknyugatDunántúlon meghatározóak, döntöen a dél-német és az osztrák gazdasági térhez kapcsolódnak, így ezen régiók gazdaságának változása érzékenyen érintheti a térség gazdasági folyamatait.

- A térség mezőgazdaságának adottságai sokoldalúak; kedvező termőhelyi feltételek (gabona és az ipari növényeknek), öntözési lehetőségek, országos átlagot meghaladó csapadék, legelö gazdálkodásra alkalmas területek, olcsón elóállitható tömegtakarmányok, állattenyésztés egyes ágazataiban magas színvonalú termelés (tej, hústermelés), híres borvidékek, zöldség termelések számottevô tradíciói és kialakult piaci kapcsolatai. A többségében külföldi tulajdonba került élelmiszergazdaság fejlett, egyben ágazati szerkezete is sokoldalú (hús-, tej-, cukor-, szesz-, édes-, növényolajipar), magas termelési kultúrával rendelkezik, az EU piacok kỏzelsége, $\mathrm{s}$ folyamatos kapcsolat más külföldi piacokkal és termelökkel a termékszerkezet rendszeres megújítását ösztönözte. A térségben megjelentek a külföldi mezógazdasági vállalkozások, ami sajátos - az árrendszer és a támogatások miatt nem egyenrangú - versenyhelyzetet teremtett, ez vélhetöen jobban ösztönzi a mezógazdaságban a tókekoncentrációt, a termékszerkezet váltását és a specializációt, miközben egyre több kisgazdaság felszámolásával, vagy tartós vegetálásával kell hosszú távon számolnunk.

- A turizmus több alrégióban jelentős, míg föleg a Balaton térségében meghatározó, jövedelemtermelö szektor. Az idegenforgalmi kínálat elemei szinesek az Északnyugat-Dunántủlon, hiszen nemcsak az egyszerü pihenéshez, a kikapcsolódáshoz nyújtanak szélesedö lehetőségeket, hanem az egyre nagyobb számban jelentkezỏ speciális turizmushoz (gyógy-, falusi-, öko-, kerékpáros-, sport-, természetjárás, kulturális) is rendelkezésre állnak akciók, az adottságok még teljesebb 
kihasználását, nem a szakképzettség, a vállalkozói potenciál, hanem döntően a tőkehiány akadályozza.

- Mérsékelt munkanélküliség (7-10\% között), számottevö a vállalkozás aktivitás, annak dinamikája viszont csökkent, ami a gazdasági szervezetek lassú stabilizációját jelezheti. A munkaerő-állományt a térségben az egyre látványosabban növekvö szolgáltatások szívják fel. Az országhatár menti megyékben nagy számban (12-15 ezer fö között) jellemzö a napi ingázás a szomszédos Ausztriába, mindez a politikai kellemetlenségeken túl, bỏvíti a térség népességének termelési ismereteit, növeli a jövedelmeket, ami a vállalkozás aktivitás további élénkítéséhez és a lokális-regionális piac bövüléséhez vezet.

- A bontakozó modern üzleti szolgáltatások egyre sokoldalúbb tevékenységekben jelennek meg, országosan magas arányt képviselnek a pénzügyi szolgáltatások, a bankfiók ellátottság kiemelkedö, azonban ezek a szervezetek a nagy- és középvárosokban koncentrálódnak, így a vidéki térségek ellátottsága még gyenge, szegényes.

- A térségben kirajzolhatók a gazdaság teljesítőképessége alapján a fejlõdési (innovációs) magterületek döntően a multifunkciós nagyvárosok körül és a Balaton térségében, ahol az országos átlagnál élénkebb a gazdasági miliō. A nyugati határ mentén egy potenciális innovációs sáv formálódik, amelyben stabil a munkavállalói pozíció és számottevő a külfơldi tőke, de alacsony a vállalkozói aktivitás.

- Erös polgári beállitottság, nagy hagyományokkal rendelkezö történelmi városok, a népesség fóleg a határ menti térségekben folyamatos információkat és kapcsolatokat gyüjt az európai fejlödés magterületeiröl, ezeket a kialakult rendszereken (vállalkozásokon) keresztuil közvetítik az ország más térségeibe.

- Élénkülö a helyi társadalom, a kistérségi szervezódések megjelentek, a mikroregionális fejlesztési programok kidolgozása megkezdődött, a lokális és a térségi infrastruktúra-hálózatok fejlesztése megindult (pl. víz, gáz, szennyvíz hálózat kiépítése, regionális hulladék-elhelyezés).

- Több megye a multiregionális együttmüködés tagja (Alpok-Adria Munkaközösség), létrejött egyes határ menti megyékkel és régiókkal az intézményes kooperáció (Határ Menti Regionális Tanács: Györ-Moson-Sopron, Vas, Burgenland), megkezdődött az INTERREG II. - PHARE CBC program, amely sokoldalúan fejleszteni kívánja a határ menti együttmüködéseket, több tervezet van a kapcsolatok kibővítésére (Eurorégió, Phare programok kiszélesítése más határtérségekre) (2. ábra).

- A vállalkozásfejlesztés intézményei mindegyik megyében kiépültek, szerveződnek a gazdasági szereplők (kamarák), együttmúködésük a területi és helyi önkormányzatokkal megkezdődött, a partnerkapcsolatok egyes elemei már felismerhetők.

- A térség megyéi rendelkeznek önálló területfejlesztési koncepciöval, így a megyefejlesztés tudatos irányai adottak, s ezekben már meghatározó szerepet kapott a térségi együttmúködés, annak erősítése. A nagy-és középvárosok közül csupán néhány rendelkezik fejlesztési koncepcióval (helyi gazdaságfejlesztési programmal), ezek keretében megkezdődött az ipari-szolgáltatói infrastruktúrájuk megújítása, illetve a telephelykínálatuk szélesítése (ipari parkok, vállalkozói zónák, inkubátorházak). 


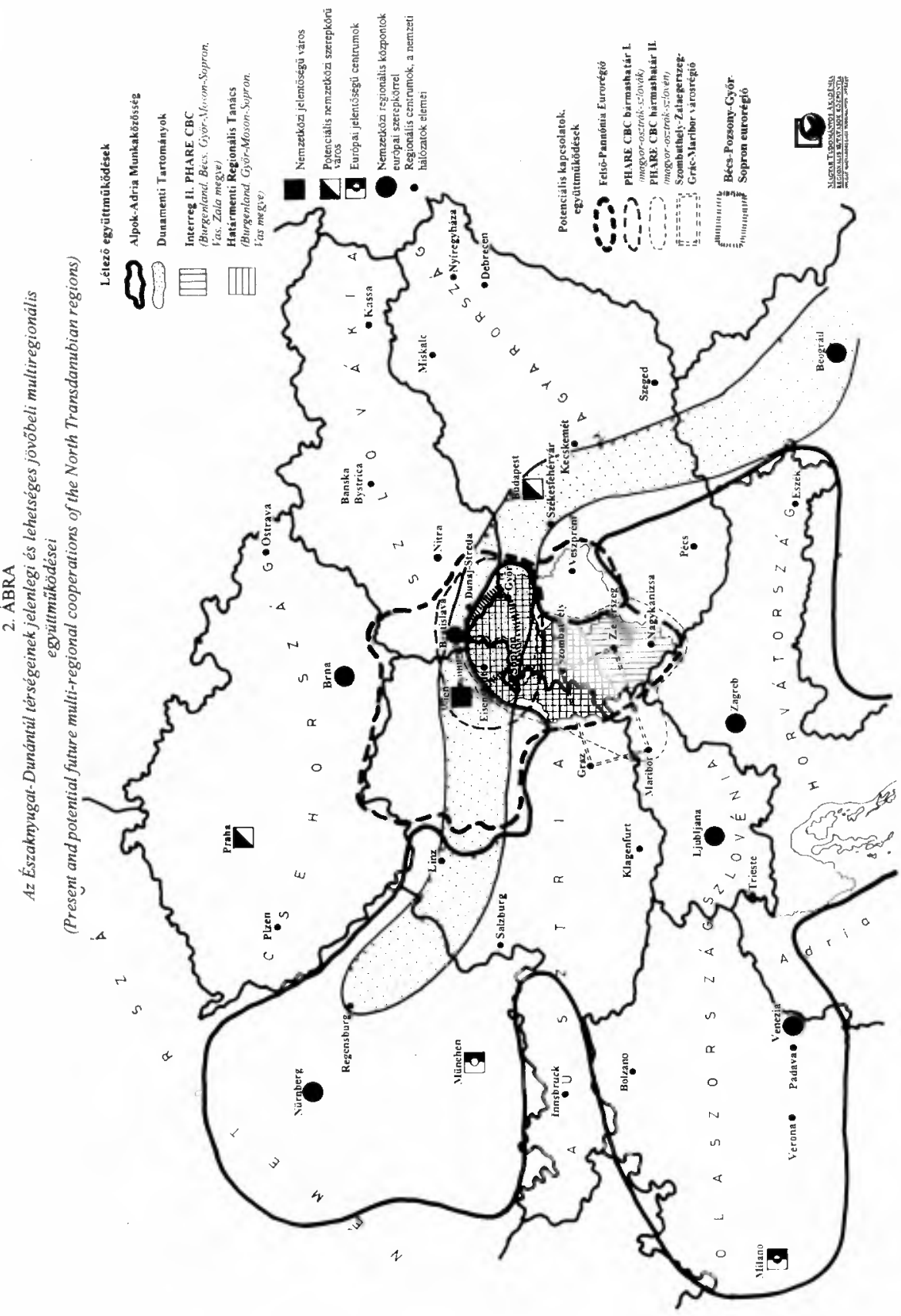


- A területfejlesztés központi forrásaiból a térség - kivéve Vas megyét - támogatást az elmúlt években nem kapott, de a különféle területfejlesztési szereplök nagy aktivitást mutattak az elérhetỏ nemzeti költségvetési alapok megpályázásában, amely ugyan eltérő eredményességgel, de hozzásegítette a helyi források bövítését.

- A kedvező gazdasági, jövedelmi és foglalkoztatási helyzet következtében a térségnek a nemzetközi és hazai ismertsége jó, az imázsa egy fejlődő, megújításra képes és alkalmas, országos viszonylatban is kiemelkedỏ telephelyi adottságokkal rendelkező régiót tükröz. Megfeleló alap áll tehát rendelkezésre egy átfogó térség- és telephelymarketing kidolgozásához és érvényesítéséhez.

\subsection{A térség adottságai: gyengeségek}

- Megosztott a térség, a gazdasági bázisok és a települések ellátottsága különböző, így az országos és térségi viszonylatban fejlettebb magterület (Györ-Moson-Sopron), a felzárkózó, a szerkezeti átalakulás alatt lévö, modernizációs hatásokat mutató, de gazdaságában erősen függő helyzetű megye (Vas), a gazdasági szerkezetének átalakulásával küszködő, települési funkciókban, térbeli szerkezetben erösen polarizált, s egyben a helyét kereső megyék (Veszprém, Zala).

Az Északnyugat-Dunántúl egyes térségeiben és centrumaiban a gazdasági potenciál kimondottan mérsékelt. Erösen tagolt belső (Bakony-vidéke, Marcal és Rábamedence, Rábaköz) és külső (szlovén-horvát határ mente) perifériára szakad szét a régió, amelynek a gazdasági adottságai és lehetőségei a jövőben igencsak korlátozottak, így hosszú távon kell számolni a térségen beliuli számottevõ területi különbségekkel, azok tartós fennmaradásával.

- A térség népességének elöregedése követi az országos tendenciákat, de a településhálózati megosztottsága ettől eltér. A nagyvárosi és a városi népesség elöregedése az ezredforduló után számottevöen növekszik, sőt annak mértéke meghaladja a községi népesség elöregedését, így az egyre bövüló szociális és foglalkoztatási feszültségekkel kell a városhálózatban hosszú távon számolni. Az ezredforduló után csak rövid ideig (2000-2005 között) növekszik a munkába lépő aktív népesség száma, majd ezután annak jelentős csökkenését kell regisztrálnunk ( 18-20 évesek száma hosszú távon 2025-ig 75 ezerről 44 ezerre csökken).

A térségben a termelö szektor intraregionális kapcsolatai gyengék, hiányzik az összetartozás, minimálisak a kölcsönös, esetiek a kooperációs szállítások. A jelentős export mögött többségében a könnyüiparban (textilruházati, cipöipar) nagytömegü, munkaerö-igényes termelés a meghatározó, a többségében külföldi tulajdont képviselö vállalkozások erre alapultak, így a külfơldi piaci kitettségük nagy, illetve érzékenyen reagálnak a termelési költségek változására.

- A mezőgazdasági foglalkoztatottak aránya az országos átlagnál jobban csökken, hasonlóan az agrárvállalkozások száma is ezen méröszám alatt van, így a mezögazdasági munkanélküliek száma a kedvezötlen adottságú térségekben a megélhetési gondok és a társadalmi feszültségek kỏvetkeztében növekszenek. Hiányoznak a programok mind a rurális térségek fejlesztéséhez, mind pedig az agrár szerkezetváltáshoz. 
- Nemzetközi mércével fejletlen infrastruktúra; föleg a közlekedés, távközlés területén. Mennyiségükben és minőségükben nem megfelelöek a régió észak-déli közlekedési kapcsolatai (82., 83., 84., 74. utak), míg a nyugat-keleti összeköttetések (85., M8., 71. utak) erősen túlterheltek, a teljesítményük határára jutottak, a telefonellátottság csak a nagyközpontokban és a szűkebb vonzáskörzetében megfelelö, a vidéki térsége között jelentős ellátottsági színvonalbeli különbségek vannak. (3.ábra)

- Az „európai kapuk”, a határátkelők szűk keresztmetszetúek és sokoldalú szolgáltatások nyújtására kevésbé képesek, a határon átnyúló kistérségi egyưttmükődések terjedését akadályozzák az átkelőhelyek hiányai.

- A regionális szintü együttmũködés és együttgondolkodás teljes hiánya, esetenként vannak megye-megye kapcsolatok, de azok sem dominánsak. Nem beszélhetünk sem funkcionális, sem fejlesztési régióról ${ }^{3}$, a gazdasági régió néhány kimondottan kezdetleges jegye viszont felismerhető (fejlödési magterületek, klasztercsírák, szerveződő kapcsolatok, országostól el téró gazdasági aktivitás stb.). Az intézményes kapcsolatokra csupán egy-két, regionális szintü együttmủködést segítő intézmény müködik (pl. Határmenti Regionális Tanács, VEAB, Balatoni Regionális Tanács), hiányzik a térségi szintü - elemi - fejlesztési koordináció (pl. megyehatár menti kapcsolatokban csak a települési önkormányzatok szintjén figyelhetö meg együttmüködés). Tapasztalhatók a megyék között a latens és a valós érdekellentétek (pl. dekoncentrált szervezetek telepítése, intézményhálózat átalakítása, infrastruktúrák kiépítése).

- Alacsony az innovációs potenciál, a K+F intézmények leépültek, megosztott, számos párhuzamos jegyet felmutató felsőoktatási bázis, az integráció csak elvekben létezik. gyakorlatban nem kezdődött meg, miközben eröteljes versenyhelyzet alakult ki az intézmények között (4. ábra).

- A naguvárosok versenye a regionális funkciókért állandósuit, vannak történelmi ellentétek, vélt vagy valós fenntartások a másik központtal szemben (Sopron-Györ, Szombathely-Györ, Veszprém-Győr, Nagykanizsa-Zalaegerszeg). A térségben a szerepkörök többirányú megosztottsága miatt nem egyértelmú éppen regionális centrumot képviselö Györ megítélése, hiszen a modern üzleti szolgáltatásokat (pénzügyi, bank, biztosítás, gazdasági-üzleti) térségi szinten koncentrálja, szervezi, de ugyanakkor az egyetem és a $\mathrm{K}+\mathrm{F}$ bázis hiánya miatt funkciói még hiányosak. A többi nagvvárosban is sokoldalúan jelen vannak az új gazdasági aktivitást képviseló szerepkörök, ezek részben a városok között kiegészitik egymást, de többségében azonosságokat mutatnak, így hatásuk nem regionális, hanem elsődlegesen megyei, vagy annál nagyobb (megyehatáron átnyúló) térségi viszonylatban jelentkezik. A középvárosok többsége mezoregionális (megyén belüli térségi) kapcsolatokat és funkciókat mutat fel, a kisvárosi hálózat hagyományokkal rendelkezỏ elemei képesek a kistérségi szerveződéseket organizálni, s önálló gazdasági (ipari, szolgáltatói) arculatot kialakítani. A nem tradicionális (üj) kisvárosok egy nagyon szúk településkör ellátását szervezik csupán, térséget átszelö városhiányos övezettel amely a megyehatárok mentén koncentrálódik - együtt egy karakteres, leszakadó zónát alkotnak, megjelenítve egyben a belső perifériák minden gondját.

- Koncentrált környezeti problémákkal sújtott a térség; a Duna eltereléséböl fakadó vízpótlás ökológiai gondjai a Szigetközben jelentkeznek, a volt bányavidéken a karsztvizek elvesztéséböl fakadó tartós szint- és hőmérsékletcsökkenéssel kell számolni (Tapolcai-medence, Dunántúli-középhegység), mig a nehézipar és a bányászat volt központjaiban (Ajka, Várpalota) a lég- és porszennyezés okoz problémát, illetve akadályozza a gazdasági szerkezet átalakítását. 


\section{3. ÁBRA}

Az Északnyugat-Dunántúl néhány területi jellemzöje $a z$ EU országok átlagában* I. (EU átlag $=100 \%$ )

Spatial characteristics of North-West Transdanubia (EU avarage $=100 \%$ )*

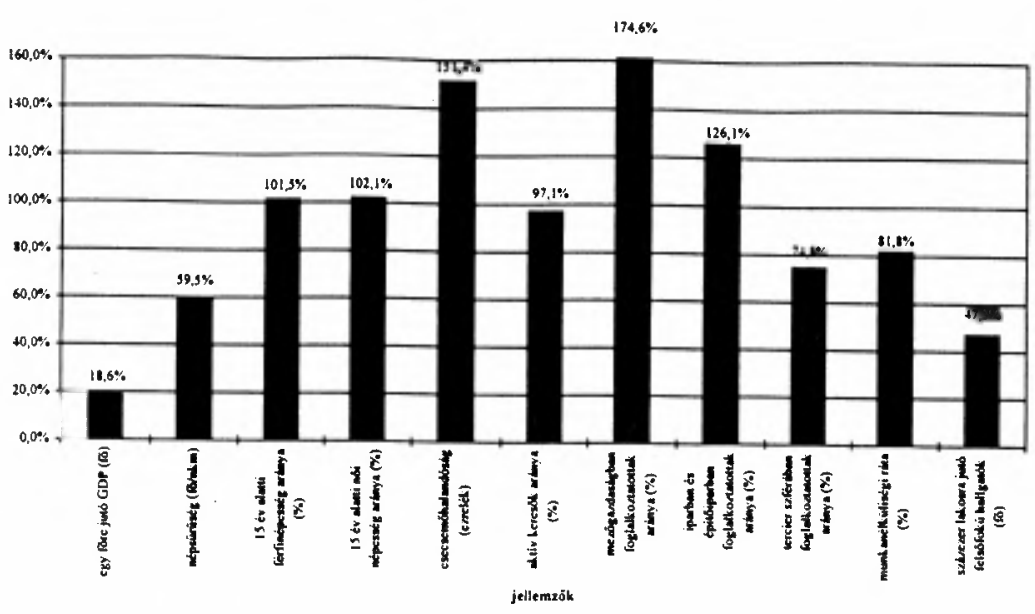

Az Eszaknyugat-Dunántúl néhány területi jellemzöje az EU országok átlagában* 11 . (EU átlag = $100 \%)$

Spatial characteristics of North-West Transdanubia (EU avarage $=100 \%$ ) *

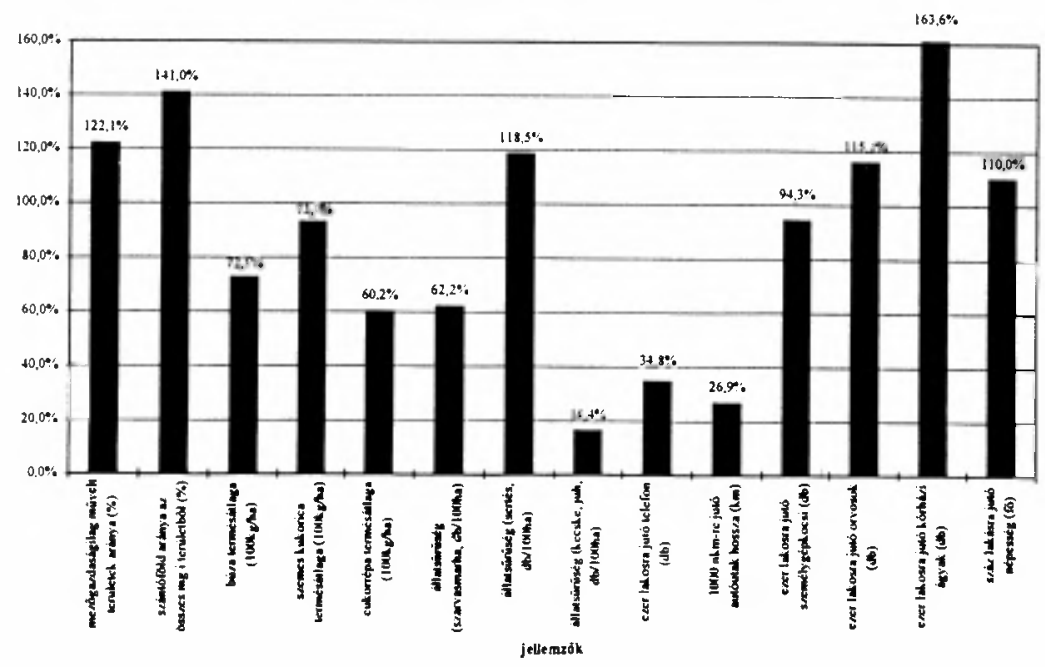

* EU: 12 member countries - at the beginning of 1992 North-West

Transdanubia - at the and of 1994.

Source:EUROSTAT 1995., Területi statisztikai évkonyv, 1994 

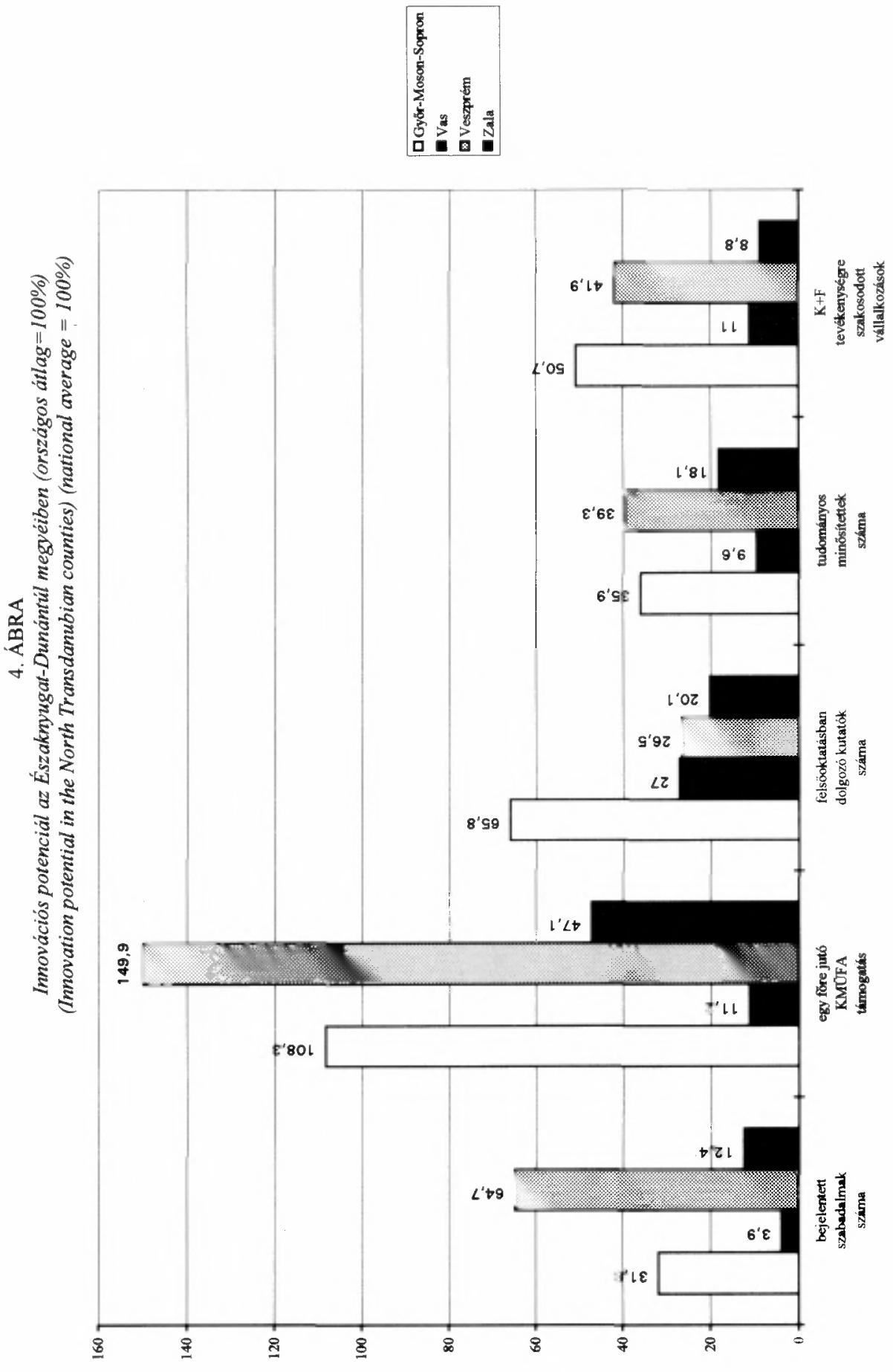


\subsection{A külső környezet változásai: lehetöségek}

$\checkmark$ A térség része egy jövőbeli európai fejlödési zónának, a Bécs-Pozsony-Gyơr-Sopron potenciális eurorégiónak, annak átgyürüzö hatásait sokoldalúan hasznosíthatja. Ugyanakkor vannak együttmüködö városrégiók; Sopron-Bécsújhely-Kismarton, valamint az erósödő bilaterális kapcsolatok is alkalmasak azok multilaterális irányban történő fejlesztésére; Szombathely-Graz, Zalaegerszeg-Maribor, illetve a kis(városi)térségi együttmúködések (pl. Szentgotthárd-Güssing), így a térség sok szállal kapcsolódhat az európai gazdasági térhez. (2. ábra)

$\nabla$

Az ország nyugat-keleti orientációja mellett a térségben a növekvó európai észak (balti térség) - déli (mediterrán övezet) együttmüködés hatásai is érvényesülhetnek (pl. új közlekedési és energetikai hálózatok), aminek a következtében egyes, eddig periférikus mikrotérségek aktivizálódhatnak.

2 A térség, ezen belül az országhatár menti központok a belsö vándorlás célpontjai lehetnek, nem tömegesen, de érzékelhetően. Mindez növeli az innovatív munkaeröállományt, söt bővülnek ezen centrumokban a befektetések, ugyanakkor a lokális piacaikon a kereslet tartós növekedését eredményezi, ami a telephelyi, a letelepedési (lakás) és megélhetési költségek magasabb szintjét képviseli, mint az ország többi részében, így tovább élénkülhet a gazdasági bázis.

A természeti eröforrásai közül több kiaknázása megszủnt (szénkészlet), vagy idölegesen szünetel, csökkent szinten folyik (bauxit), illetve nem minden ismert lelőhely aktivizált (termálkészlet). Változó gazdasági környezetben ezen eröforrások új szemléletú hasznositása több mikrotérségben és centrumban lendületet adhat a megújitásnak, a fejlesztésnek.

¿ A térség erőforrásai között külön kell kiemelni a környezeti potenciált, amelynek gazdasági feltárása napjainkban indult meg, s számos új lehetőséget kínálhat, természetesen azzal a veszéllyel, hogy a meglévö értékek kifosztása is bekövetkezhet.

¿ A gazdasági partnerek képesek a fejlesztések támogatására, a térségi szintủ koordinált fejlesztések ösztönzésére, így a nemzetközi és a hazai programokban való részvételhez a szükséges források bizonyos része rendelkezésre állhat, sőt decentralizált programokkal azok megsokszorozódhatnak.

च Az intraregionális gazdasági kapcsolatok feltárása a gazdasági szereplök számára új lehetőségeket kínálhat, a multiregionális együttmüködések segíthetik a térségen belüli gazdasági kapcsolatok kiszélesítését, egyben azokat jól integrálhatják.

ヌ A megyei fejlesztési stratégiák szorgalmazzák a térségi szintü együttműködést. A regionális fejlesztési stratégia kidolgozása kedvező fogadtatást kapott, szükségszerủen meg kell alapítani a térség fejlesztésének intézménvét. A területfejlesztési források egy részének és a nemzetközi programoknak decentralizálása (INTERREG II. - PHARE CBC) lényegében megtörtént, az ezekben rejlő lehetôségek kihasználása viszont még nem kellően szervezett (pályázatok előkészítése, térségi szintü programok indítása, azok menedzselése, a különféle megyei szintú kezdeményezések összehangolása, a megyehatár menti térségek együttes fellépése, kölcsönös támogatása stb.).

『 Gyorsabb modernizáció, a dinamikusabb felzárkózás érdekében a térség nagyobb országos politikai és gazdasági támogatottságot kaphat, hiszen bizonyítható eredményeivel a kormányzati és egyben a területfejlesztési politika sikere, illetve a kisebb költségvetési hozzájárulás mellett (pl. nemzetközi programoknál a saját erö meghatározott hányadának biztosítása) jelentös bevétel biztosítható a térségi szereplők gazdasági aktivitásának fokozásából. 
邓 A helyi önkormányzatok felismerték, hogy a fejlesztési forrásaikat csak úgy bővíthetik, ha kistérségi együttmüködéseket szerveznek. Ezek közül több részben átnyúlik a megyehatárokon, részben egymáshoz közelálló, hasonló helyzetben (elmaradott, rurális térségek) lévő mikrorégiókat érintenek, így lehetőség kínálkozik a közös problémák együttes megoldására, a koordinált kistérségi fejlesztési programok kidolgozására.

2 A térség kedvezö arculattal, imázzsal rendelkezik, ami az elönyös hazai és nemzetközi megítéléséből következik, így sikeresebben tudja adottságait kiajánlani.

\subsection{A külsö környezet változásai: veszélyek}

Q A térségben a demográfiai folyamatok 2005-ig alakulnak elöremutatóan, azaz mérsékelten, de emelkedik a munkába lépö népesség, viszont ezen időpont után megkezdődik a népesség gyors elöregedése, föleg a nagyvárosokban. A munkaerőigényes gazdasági bázisok telepítését tehát már középtávon, lényegében az ezredfordulóig be kell fejezni, s azok térben elsődlegesen Győr-Moson-Sopron és Veszprém megyét érinthetik, mert a másik két megyében (Vas, Zala) jelentősen csökken a munkába lépő́k száma, munkaintenzív szerkezetalakításnak a tartós feltételei kellóen nem biztositottak.

৫ A regionális identitás hiányzik a térségből. A területi egységek és a centrumok lényegében eddig önmaguk érvényesültek, nem voltak rászorulva az együttmüködésre, ha azok voltak is, kimondottan multiregionális viszonylatban jelentek meg. Nem egyértelmũ a térség regionális szervezödése, hiszen több változatban elképzelhető a "felállás", sőt a potenciális tagok különféle regionális érdekeltségekben már jelen vannak, így nagy veszélye van a "kvázirégió" létrejöttének.

৫ A térségben félelmek és - megalapozatlan - fenntartások alakultak ki az erősebb, a „gazdagabb" megyékkel, nagyvárosokkal szemben, ez további megosztottságot jelenthet, s korlátozhatja az együttmúködéseket. A megyék csak látszat kapcsolatokat létesítenek, a területfejlesztés többi szereplöje alapvetően megyei szinten érdekelt (tagság, választás, támogatások, eredmények demonstrálása), igy a létrehozandó regionális intézmények múködése akadozik, elismertsége gyenge lesz, valós akciókat nem lesz képes szervezni.

口 Belpolitikai konfliktusokat gerjeszthet a térség. Hiszen az országon belül a nyugatkeleti regionális különbségek jelentős mérséklődése közép távon nem várható, így a központi kormányzat kénytelen lesz a fejlettebb térségek támogatásainak csökkentésére (a decentralizált fejlesztési források átrendezésére ${ }^{6}$ ). Az ÉszaknyugatDunántúlnak az elmúlt 6-7 esztendöben nem volt karakteres politikai érdekérvényesítő képviselete, nem szerveződött meg a regionális lobby, a politikai aktorok ezirányú gondolkodása nem alakult ki, ami a pártállások megosztottságának is köszönhető, de annak is, hogy a térségben nem voltak égető gazdasági és társadalmi problémák.

Q Burgenland a jelentősebb külföldi beruházókat elszivhatja, azokat "megállíthatja" a nagyságrenddel magasabb, kimondottan EU támogatások miatt (Célterület 1), így a multiregionális együttmüködésben érdekellentétek keletkeznek. Ezek a konfliktusok abban is érvényesülnek, hogy az INTERREG II. - PHARE CBC program magyar kezdeményezéseit az osztrák félnek kell véleményezni (lényegében jövőben a régió fejlesztésének ez lesz az egyetlen garantált külső forrása), így a komplementer vagy versenyfejlesztéseket fenntartással támogatják, sőt azok előkészítését is korlátozzák az EU forrásokból ( $p l$. regionális repülőtér, vasúti kapcsolatok, ipari parkok, termálturizmus stb.). 
口 Szlovákiával az együttmúködések akadoznak. A bilaterális kapcsolatok nem alakulnak az ismert tényezők miatt (nemzetiségi kérdés, dunai vizierömű), talán az osztrák-magyar multiregionális együttmúködések segithetik a kapcsolatok intézményesülését, de nem várható éppen a közel azonos gazdasági helyzet miatt, hogy a szlovák viszonylat jelentős térségfejlesztỏ eröt képvisel.

৫ Szlovén viszonylatban viszont áttörés várható, azonban a kedvezőtlen kőzlekedési összeköttetés mindenféle elmélyült kapcsolatot akadályoz, sỏt a határ menti térségekben csupán az azonos fejlettségü mezógazdaságban lehetnek kooperációs tevékenységek, mindezt még nehezíti a szomszéd országban a regionális vagy a területi közigazgatási sżint hiánya.

口 Horvátország újjáépítésébe a térség bekapcsolódhat, de ezt akadályozza a közlekedési kapcsolatok hiánya, illetve a területek és azok gazdaságának azonos jellege, sőt a megfelelö partnerek hiánya is.

\section{A térség jövóképének lehetséges forgatókönyvei}

A térség jövöképének lehetséges forgatókönyveit az ország térszerkezetének különféle gazdasági és társadalmi fejlỏdési elképzeléseiből vezetjük le, keresve ezekben a térségünkre vonatkozó sajátosságokat, azokat a másságokat, amelyek ezen fejlödési pályák alapján az Északnyugat-Dunántúlra érvényesek lehetnek.

\subsection{A domináns megyefejlódés modellje}

A forgatókönyv alapját a polarizált regionális fejlódés modellje nyújtja, ami szerint a gazdaság stagnálása elhúzódik, csak a 2000. év után képzelhető el egy dinamikusabb növekedés. A területi szerkezetben a meglévő nyugat-keleti különbségek tovább fokozódnak, határozottabb fejlödés figyelhetó meg a Dunántúlon, illetve a fóvárosban. Ezek a térségek jobban vonzzák a befektetéseket, a hazai és külföldi töket, de egyben a korszerủ, nagyobb versenyképességü ipari tevékenységeket, s a kevésbé tudásigényes iparok fokozatosan kitelepülnek a nagyobb és egyben olcsóbb munkaeró kínálatot nyújtó keleti régiókba.

A térségben a nagyobb centrumok (megyeszékhelyek, nagyvárosok) fejlödése gyorsabb lesz, itt megkezdödik az ipari infrastruktúra fogadási feltételeinek látványos kiépitése. Egyben mindez nóveli a versenyt a centrumok kơzôtt, ami lényegében ellene hat a regionális szervezödésnek, hiszen az egylittmüködést gátolja az eróforrásokért (befektetök, munkahelyek) vivott küzdelem.

A tercier funkciók élénkülése is a nagyközpontokban lesz látványos, ugyanakkor nem tơrténik meg alapvetően a felsőoktatásban az intézményrendszer szervezeti és tartalmi kapcsolatainak a kialakitása, ami rontja a térség egészének fejlódési esélyeit.

A térség - föleg a hatår menti zónák és a nagycentrumok - a népességmozgás intenziv célpontjává válik, ami feszültséget teremt a helyi lakosság és a bevándorlók közótt. Az infrastrukturális hálózat, igy az interregionális kapcsolatok jelentősen nem javulnak, föleg az úthálózat átbocsátóképessége nôvekszik, kiegyenlítettebb lesz a kommunikációs infrastruktúra, de ezek együttesen sem járulnak hozzå a regionális szervezödéshez, a belsö kohézió erösítéséhez. 
Hasonlóan nem erősíti a regionális kapcsolatokat, hogy a térség szerkezeti megosztottsága nem csökken. Éppen a centrumok és térségeik intenzívebb fejlödése miatt a megyehatár menti perifériák helyzete nem változik, azok népesség csőkkenése egyre látványosabb lesz a területek kiürülnek, ami a társadalmi feszultségeket fokozza, illetve egyre tỏbb területi (megyei) eróforrást köt le.

A kisvárosi hálózat - kivéve az országhatár menti zónákban - sem lesz képes aktivizálódni, ugyan megszünnek a térségben a városhiányos övezetek, de az új és régi centrumok nem válnak a kistérségi szervezódések valós centrumaivá.

A térségben - éppen a tơrvény hatására megszervezödik a regionális együttmüködés intézménye, azonban annak mükơdése akadozik. A megyék még önmaguk keresik a lehetséges mozgástereket, nem képesek egységesen fellépni a multiregionális kapcsolatokban, az ottani lehetôségeket onmagukban kisérelik meg kihasználni.

Lezárul az INTERREG II. - PHARE CBC program elsó szakasza, ebben több látványos program valósul meg, azonban ezek nem járulnak számottevóen hozzá a térség teljesebb felzárkózásához az osztrák régiókhoz, viszont jó alapot teremtenek ahhoz, hogy a regionális szerkezet kedvezó irányba változzon, a multiregionális kapcsolatok erösödjenek, s a térségi szereplők nagyobb ismereteket szerezzenek az EU gyakorlatáról.

A gyenge regionális együttmüködések nem ösztönzik a szomszédos osztrák régiókat arra, hogy létrejöjjön a Bécs-Pozsony-GyörSopron/Felsö-Pannónia Eurorégió, így annak érdekérvényesitése, föleg az EU forrásai felé nem történik meg. Nem sikerül jelentősen elörelépni a szlovák határ menti kapcsolatokban sem, ezt fóleg a változatlanul gyenge infrastrukturális egybefüzõdéseken túl akadályozzák a két ország közötti tartósan meglévő feszültségek, illetve az, hogy a gazdasági fejlettségi szintek lényegében kiegyenlítettek, azaz egymásnak számottevő eröforrást nem tudnak a térségek átadni.

$\mathrm{Az}$ országos gazdasági erôforrások mérsékelt növekedése miatt a kormányzati forrásokból a térség részesedése jelentősen nem növekszik, söt annak kisebb méretü csökkenésével számolhatunk. A kiélezettebb nyugat-keleti regionális különbségek változatlanul a keleti országrészek felzárkóztatását kényszerítik ki a kormányzattól. A politikai feszültségek szintjére emelkedik a területi differenciák elmélyülése, amelyek viszont a területpolitika folyamatos korrekcióját követelik meg, illetve a megkezdett decentralizáció fokozatos korlátozását eredményezik.

Nem nónek számottevően a térségben a területfejlesztés rendelkezésre álló forrásai, hiszen sem a területi, sem a helyi önkormányzatok nem tudják emelni bevételeiket, s a gazdasági szereplök éppen a külsỏ források hiánya miatt, nem kapcsolódnak be látványosûn a forrás növelésbe, csak a mérséklödő decentralizált alapok elosztásába.

\subsection{A regionális együttmüködés modellje}

A forgatókönyv alapját a közepesen koncentrált regionális fejlödés modellje adja, ami szerint a gazdasági növekedés felgyorsul és annak területi terjedése egyenletessé válik az országban. Mérséklődnek tehát a térségi különbségek, mindez viszont kedvezóen hat az Északnyugat-Dunántúlon a regionális együttmúködések megjelenésére, hiszen egy kiegyensúlyozottabb gazdasági miliőben a megyék összefogása gyorsabb fejlödést tesz lehetővé.

A térség gazdaságában a jelenlegi ipari klasztercsírák egyre látványosabbá válnak. Megerósödnek a gépipari-autóipari termelési kooperációk (Győr-Szombathely, Szentgotthárd), továbbá a faipari- épitöanyagipari és bủlor-, lakberendezés-ipari együttmüködéseken (Györ-NagykanizsaSopron-Szombathely-Zalaegerszeg-Veszprém) túl megjelennek a környezetvédelmi- és hasznositási ipari bázisok (Veszprém-Sopron). 
Ezen három domináns ipari klaszterre egyre tơbb kis- és középvállalkozás füződik fel, igy térben is jobban megosztottá (centrumok vonzáskörzete és a kisvárosi hálózat kapcsolódó elemei) válik a nagyobb tudásigényt kơvetelő iparok terjedése.

A formálódó ipari egyuuttmủkođési csoportok változó infrastruktúra igénye (ipari parkok, kis- és kőzépvállalkozói zónák) mellett növekszik a kereslet a térség szellemi erőforrásai iránt. A felsôoktatási együttmüködések egyre határozottabbá válnak, fóleg az egymáshoz kőzelebb lévó centrumokban (Györ-Mosonmagyaróvár; Szombathely-Sopron; Veszprém-KeszthelyZalaegerszeg), söt megkezdódik a $K+F$ kapacitások kiépülése is (innovációs és technológia-transzfer központok; Györ, Veszprém), de éppen a speciális igények következtében az at- és továbbképzésekben is megindul a térségi szintü egybevetés, egyeztetés (Szombathely, Györ).

A térség mezôgazdasága csak a termötáji adottságainak jobb kihasználásával fokozhatja jelenlétét a külfơldi piacokon. Mindez a zőldség és gyưmölcs termelés megújitását eredményezi jelentôs fajtaváltással, s a borvidékek minóségi átalakulását. $\mathrm{Az}$ állattenyésztésben a feldolgozottsági szint átfogóbb nơvelése viszont az ÉszaknyugatDunántúl élelmiszeripara fejlódésének adhat új lendületet.

A tercier funkciók látványos terjedését regisztrálhatjuk, ezek már nemcsak a nagykőzpontokhoz kötődnek, hanem a középvárosokhoz is, söt egyre több (alap)szolgáltatás már megfeleló színvonalon lesz elérhetố a tradicionális kisvárosokban is.

\section{A hatórmenti nagycentrumok (Sopron,} Szombathely, Nagykanizsa, Mosonmagyaróvár) nem veszitenek multiregionális vonzásukból, söt bövülnek funkcióik, illetve a határok (osztrák-magyar, szlovén-magyar, szlovákmagyar) egyre szabadabb átjárásával térségszervezö szerepưk növekszik, miközben a kisebb és speciális funkciókat kínáló centrumokban (Köszeg, Körmend, Szentgotthárd, Lenti, Letenye) is élénkül a határgazdaság ${ }^{6}$.

Magyarország EU tagságával lényegében lebomlanak azok a gazdasági (vámok, áruszállitási, minősitési követelmények) korlátok, amelyek a térség orientációját a föváros felé kényszeritették. A gazdasági szereplök egyre nagyobb hányadban a beszerzéseiket és értékesítéseiket a közeli európai gazdasági centrumokból bonyolítják, igy a térség még erösebben kapcsolódik ehhez a gazdasági térhez.

Ugyanakkor számos termelési és szolgáltatási tevékenységben (nagyobb aktivitással a turizmusban ezen belül) megjelennek a külffoldi befektetôk, vállalkozások, igy egy fokozott és kiélezett versennyel kell szembenéznie a térség gazdasági szereplőinek, ami viszont hosszabb távon kikényszeríti a regionális tőke koncentrációt, a minőségi termelést és az átfogó piacpolitikát, térségmarketinget. Az ország EU tagságának kedvezö következménye mellett éppen az Északnyugat-Dunántúlon kell számolni a megjelenö negativ területi hatásokkal ${ }^{7}$, hiszen az itteni erösođỏ gazdaság érzékenysége ebben az idószakban még nagyobb, viszont a jelentösebb felvevő piacai szükségszerüen vonzzák a tókeerősebb külfơldi vállalkozásokat.

A térség kivételezett helyzete megszünik, hiszen lesz tơbb EU-határrégió, viszont, mint elmaradottnak tekinthető EU-belső határ, továbbra is számithat a speciális fejlesztési támogatásokra. A multiregionális kapcsolatoknak inkább a minösége bövül, nem lehet számítani arra, hogy újabb infrastrukturális (közlekedési) folyosók nyílnak meg, a meglévök fejlesztése várható (megközelités, áteresz-tőképesség), viszont azokban a forgalom növekszik, éppen az orientáció fokozatos váltása miatt. Több kistérségi határátkelö is létesul, amelyek fontos 
alapegységei lesznek a határokon átnyúló kapcsolatoknak.

A térség belsö, intraregionális kapcsolatai javulnak, az észak-déli ơsszeköttetésben inkább a minőségi változásra lehet számítani, míg a nyugat-keleti irányban viszont gyorsabb, biztonságosabb lesz a régió átjárása. A régióban logisztikai központok létesủlnek (Györ; Sopron, Szombathely, Nagykanizsa), ezek a tơbb funkciós szállitási és termékatalakítási szerepkörooket is magukba foglalják. A regionális egyuuttmüködés a megyék között egyre több szálon bonyolódik, ennek oka, hogy egyrészt a kiegyenlítettebb fejlódés nagyobb teret kínál az összefogásra, másrészt az EU források is jobban ösztönozznek az intézményes térségi kapcsolatokra. S végull az euroregionális szervezödések is kibontakoznak, hiszen a partneri viszonyok egyenlőkké válnak, így az elzárkózás helyett, célszerúbb az ơssze-fogás.

Nemcsak a Bécs-Pozsony-Györ-Sopron/FelsöPannónia Eurorégió kínál új fejlesztési lehetőségeket, hanem a Szombathely-GrazMaribor-Zalaegerszeg hármashatár térségben is megkezdódik a kapcsolatok intézményes szervezése. Az euroregionális együttmúkődések számos kistérségi konkrét kapcsolatnak a keretét adják.

A regionális együttmüködések akcióterülete a multiregionális kapcsolatok erősítése mellett döntöen a belsõ perifériákra irányul. Az intraregionális infrastrukturális kapcsolatok bővülése kővetkeztében a rurális, elmaradott térségek ráfüzödése erösödik a nagy- és szubcentrumokra.

Ugyanakkor azok népessége tovább csökken, mivel a belsö vándorlások nővekedése várható. Megkezdỏdik viszont a rurális és elmaradott térségek környezet-orientált hasznositása, illetve több forrás áll rendelkezésre a helyi kezdeményezések (önerős fejlesztési, közösségépitési és megtartási programok) támogatására. A kiegyensúlyozottabb életszínvonal lehetóséget kínál a "vidék" felèrtékelődésére, s ez tovább tágítja - föleg a nagycentrumokhoz közelebb esö - a periférikus térségek mozgásterét.

A területpolitika nagyobb forrásokkal rendelkezik, hiszen megtörténik a külónféle központi alapok összevonása hảrom célalappá (regionális fejlesztés, szociális és mezögazdasági támogatások), illetve az EU strukturális alapjai megnyílnak az ország számára. A decentralizáció teljessé válik, s abban a területi szint még a megye, de már határozott ösztönzök vannak a regionális együttmükődésre, bizonyos források csak ebben a dimenzióban érhetök el, hívhatók le. A régió fejlesztésében a partner kapcsolatok érvényesülnek, a területi, a helyi önkormányzatok forrásaihoz a növekvö és decentralizált alapok hozzáadódnak, s a gazdasági aktorok is felismerik, hogy a területfejlesztésbe történő "befektetéseknek" a gazdasági hatékonysága kedvezö. 


\subsection{A regionális integráció modellje}

A forgatókönyv a dekoncentrált regionális fejlődésból indul ki, amely feltételezi, hogy egy gyors gazdasági növekedés indul meg az országban, aminek a következtében a külföldi befektetések is látványosan megugranak. Mindezt csak fokozza, hogy az EU-tagság megszerzésével együtt jelentösen megemelkednek a területfejlesztés forrásai, így az országban a növekvő regionális különbséget csökkenteni, sőt megállítani lehet.

Az elözö forgatókönyvben leírtak jellemzik az Északnyugat-Dunántúl iparát és mezögazdaságát azzal kiegészítve, hogy az elóbbinél a klaszterek sokkal karakteresebben alakulnak ki. Gyorsabb a kis- és középvállalkozói bázis szervezödése, aminek a müködési feltételei már teljesebben garantáltak, s térbeli terjedése is nagyobb település kơrt fog át.

A mezögazdaságban egy gyorsabb átrendezödés következik be, ami nemcsak a termékszer-kezet radikális váltását eredményezi, hanem a birtokszerkezet koncentrációját is, s így a régióban karakteres termelö-feldolgozó agrártájak formálódnak ki. Ezek szorosan kapcsolódnak ahhoz az élelmiszeriparhoz, amely már térben jobban dekoncentrált, a kơzépüzemek diffúziója révén.

A tercier gazdaság válik a legnagyobb foglalkoztatást nyújtó szektorrá, a szolgáltatások elérhetösége szinte teljes, a nagyvárosokban megjelennek a szolgáltató parkok, s a régióba települ több, országos hatáskörrel rendelkezó szervezet - egy átfogó decentralizációs kormányzati program keretén belul - aminek a következtében néhány középváros új aktivitást nyer.

A felsôoktatás megosztottsága rendeződik, hiszen a három egyetemi centrum (Györ, Veszprém, Sopron) ugyan számos azonos oktatási programmal rendelkezik, de tartósan tudják biztosítani az igényes képzés feltételeit. Lényegében ezen centrumokban tömöriłlnek a nơvekvő $\mathrm{K}+\mathrm{F}$ intézmények is, de tơbb szubcentrumban éppen az egyetemi integráció miatt regionális, sőt országos jelentőségủ kutatási-fejlesztési létesítmények mükơdnek. A régió infrastrukturális hálózata fejlódésnek indul, ugyan változatlanul nem bővül a nemzetkőzi csatlakozási pontok száma, de az M7- es autópálya és M8-as autóút közelebb hozza az észak-olasz gazdaságot, igy annak befolyása növekszik. A déli és dunántúli autó-pálya szakaszos kiépulésével a régió új kapcsolatokra tesz szert. Jelentösen javulnak az észak-déli intraregionális osszekottetések, aminek következtében a periférikus térségek feltártsága javul, a régió nagyközpontjai gyorsan elérhetök.

A regionális együttmüködést már az integráció váltja fel, ami azt jelenti, hogy regionális szintre kerül a térségfejlesztés teljes eszközrendszere. A decentralizációhoz hozzátartozik, hogy lezárul a kőzigazgatási reform, s egy jóval kisebb számú, de jelentösen nagyobb jogkơrrel és erőforrással rendelkezỏ onkormányzatok alakulnak meg. A multiregionális együttmükodésben a partner ez a regionális szint (kormány), igy a térség kapcsolatai és felzárkózása Európa magterületeihez már a létrejơtt eurégiókon (az elözö forgatókönyvben megadott térségekben) keresztül tovább szélesíthetö.

A régió belsõ perifériáinak a kiürülése viszont felgyorsul, a kisvárosok mikroregionális szervező funkciója ellenben kibövul, így célpontjai lesznek a belsö migrációnak, sőt a szuburbanizáció térnyerésével - föleg a nagycentrumokhoz kőzeliekben - a népességúk stabilizálódik.

A "vidék" ugyanakkor a környezeti szemlélet látványos térnyerése - és persze a gazdasági stabilizálódás - következtében felértékelödik, igy a korábban periférikus térségek ủj szemléletü hasznosítása kezdódik meg, éppen a táji, természeti értékek fokozott védelme érdekében. Az Északnyugat-Dunántúl térsége a hazai modernizáció egyik magterülete, így a regionális szervezõdés és együttmũködés bármilyen formája lényegében ennek a modellnek a kialakulását segíti, sõt ösztönzi. 


\section{A térség missziója, a területfejlesztés stratégia alapelvei}

A térség területfejlesztésének föbb irányait tehát a földrajzi helyzet, a magas urbanizációs szint, a közlekedési folyosók mentén egyre látványosabban kiformálódó - országosnál valamivel kedvezőbb infrastrukturális ellátottsággal rendelkezó - fejlödési zónák, a népesség magasabb iskolázottsága és termelési tapasztalatai, a számottevő külföldi befektetések és térségi vállalkozási hajlandóság, s egyben a helyi és térségi piacok nagyobb fogadóképessége, azaz a gazdasági és társadalmi átmenet gyorsabb dinamikája határozza meg.

A térségben a regionális szerveződés nem kezdődött meg, vannak elemei a különféle - föként a területi önkormányzati - területfejlesztési szereplök együttmúködésének, de ezek nem karakteresek, még nem állnak össze egy határozott egységgé. A regionális szerveződés hiánya ellenére a térség mégis más karaktert mutat, mit az ország többi része, hiszen elörehaladottabb a modernizáció, élénkek a területi folyamatok, azok aktorai sokoldalú tevékenységeket folytatnak, a gazdaság fokozatosan megélénkül, a helyi piacok mellett formálódnak a térségi funkciókra törekvő szerveződések, amik a regionális piac alakítását segítik, s végül a területi egységekben, a megyékben a területfejlesztés koordinációja és tudatos alakítása megkezdődik.

Az Északnyugat-Dunántúl helyzete tehát hosszú távon kedvező a hazai térszerkezetben, söt mint a modernizációra határozottabban érett térségnek feladata is, hogy a megindult, elóremutató területi folyamataihoz éppen a regionális együttmüködéssel mutasson fel új megoldásokat.

Az Északnyugat-Dunántúl térségfejlesztési stratégiájának általános célja, hogy

$\Rightarrow$ a megindult gazdasági növekedés és elöremutató területi szerkezeti átrendeződés feltételei tartósan biztosítottak legyenek,

$\Rightarrow$ növekedjen a belsó kohézió, amihez szükséges a regionális szerveződés kưlönféle szintjeinek, szervezeteinek a kialakulása, s mindezek járuljanak hozzá, hogy a multiregionális (országhatáron átnyúló) együttmüködések sokoldalú megjelenése, azoknak a hasznositása a térség megújitásában érezhetővé váljon,

$\Rightarrow$ a megyehatárok mentén kialakult hátrányos helyzetủ mikrorégiók fokozatos felzárkózásának feltételei éppen a regionális szintủ együttműködésekkel teremtődhetnek meg, ami egyben a formálódó régió számára új területi eröforrásokat biztosít,

$\Rightarrow$ a környezeti potenciálban rejlö adottságok minél szélesebb hasznositása, $\mathrm{s}$ ezáltal a fenntartható fejlődés elvének és gyakorlatának területfejlesztési érvényesítése. 


\section{6. Északnyugat-Dunántúl fejlesztési prioritásai és programjai}

A megfogalmazott általános stratégiai célok megvalósítását a régióra vonatkozó széleskörủ elemzések alapján a következö fö prioritásokban határozhatjuk meg (5. ábra):

1. A gazdasági bázis innovációs miliőjének kialakitása (gazdasági infrastruktúra fejlesztése, szellemi erőforrások erősítése)

2. A multi- és intraregionális kohézió erősítése (országhatár menti együttmüködések, régióépítés)

3. A belsö perifériák aktivizálása (kistérségfejlesztési programok preferálása, intraregionális közlekedési kapcsolatok erösítése, települési infrastruktúra fẹlesztése)

4. A környezeti potenciál megóvása (környezeti károk felszámolása és mérséklése, ökopotenciál fölmérése)

Ezek a prioritások, az abban megfogalmazott stratégiai célok adják meg a jövöbeli akciók kereteit, fö irányait, s szolgálnak a megfogalmazandó konkrét programok, illetve az azt fölépitő konkrét projektek alapjául. A célok összessége a források koncentrált és hatékony fölhasználásának, s így a fenntartható gazdasági-társadalmi fejlődés megvalósitásának irányába hat.

Minden egyes prioritásnál, stratégiai célnál meghatározásra kerül, hogy az mely ágazat fejlesztését jelöli meg feladatként. Azonban valamely cél lehet horizontális jellegủ $(A)$ is, azaz megvalósulása esetén több ágazatban is érezteti pozitív hatását. Ezen túlmenően elkülönítjük az egyes prioritások célcsoportjait (B) is, vagyis azon szervezeteket, társadalmi csoportokat, akik leginkább érezhetik az intézkedések megvalósulásából származó pozitív hatásokat. Jelezzük az egyes prioritások területi dimenzióját is, azaz az egyes célokat területi szintekhez (a régió, a megye egésze, kistérségek, városok) rendeljük.

A stratégiai célok jellegének és célcsoportjainak meghatározását a probléma (C) rövid leírása, a jelentkezỏ szükséglet értelmezése követi: mi az adott prioritás tartalma, miért kerül kiemelésre, mi hiányzik a régióban ezen prioritásból.

A megoldásra váró specifikus kulcsproblémák és szükségletek alapján történik az egyes prioritások konkrét céljainak (D) kiválasztása, majd az azokhoz kapcsolható intézkedések (E) meghatározása, lényegében a javasolt programok rövid fölvezetése. A konkrét célok intézkedésekre és akciókra történő lefordítása képezi majd alapját az alprogramoknak és a konkrét projekteknek.

A hatékony monitoring érdekében szükség van olyan eredménymutatókra $(F)$, melyeken keresztül figyelemmel kísérhetó és mérhető a célok megvalósulása, azok sikere. Ezek szintén valamennyi célnál bemutatásra kerülnek. 
Tér és Társadalom, 11. 1997. 1. 219-269. p.

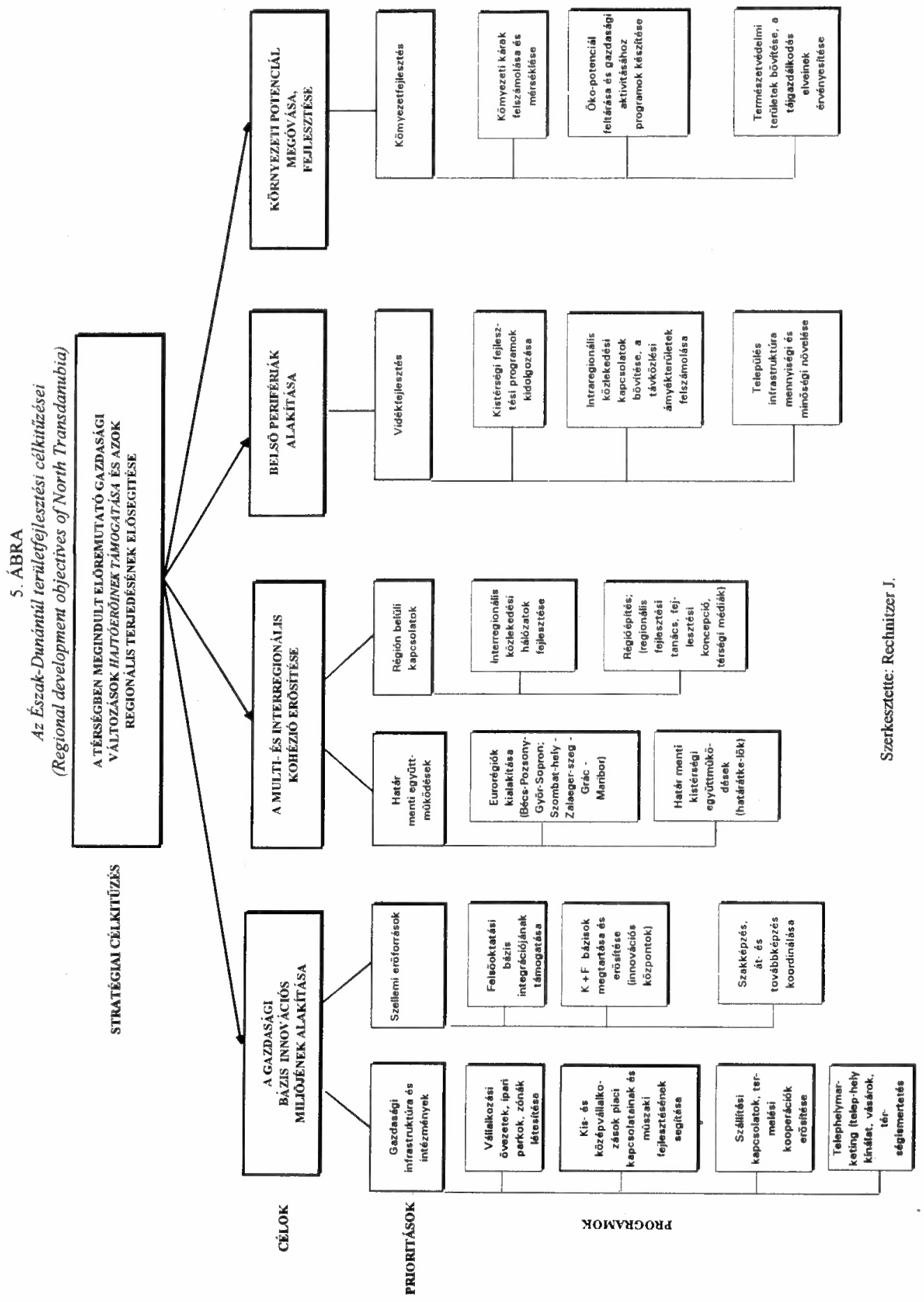


Meghatározásra kerülnek a stratégiai célok kidolgozásában, koordinálásában és megvalósításában részt vevő szervezetek $(\mathrm{G})$, azok értelmezhetó feladatai. Ezek kimunkálása csak a koordináció és a partnerség elvének bázisán lesz múködöképes. (1. táblázat) Jelezzük az egyes stratégiai célok potenciális eröforrásait is, támaszkodva az addicionálás elvében rejlő lehetöségek kiaknázására. (2. táblázat)

Adott stratégiai cél megvalósíthatóságát növeli, ha az illeszkedik magasabb szintủ programokhoz $(\mathrm{H})$, ágazati elképzelésekhez (pl. a kormány modernizációs programjához, ágazati fejlesztési stratégiákhoz, nemzetközi programokhoz). Azt is bemutatjuk, hogy a javasolt intézkedések kapcsolódnak-e más, a tervezési régióban futó fejlesztési program(ok)hoz, illetve mennyiben kötődnek más - a jelen fejlesztési stratégiában javasolt - prioritás(ok)hoz, mennyiben fedik át azok programjait (5. ábra). Ez az elemzés segítheti a források koncentrációját, azok hatékony fölhasználását.

\section{PRIORITÁS: A GAZDASÁGI BÁZIS INNOVÁCIÓS MILIÖJÉNEK KIALAKÍTÁSA}

A. Az innovációs miliö fejlesztése olyan prioritás, mely közvetlenül is kifejti hatását a gazdaság és társadalom valamennyi területén, s megalapozását jelenti a régió jövőbeli fejlödésének.

B. A programok célcsoportjába a gazdasági szféra szereplöi tartoznak. Elsősorban a kis- és középvállalkozások, de a telephely kínálat bövitése a külföldi befektetőknek régiónk iránti intenzív érdeklődésének hosszú távú megtartását is célozza. Az innovációs környezet alakításának másik fơ területe a humán erőforrások fejlesztése, amely föbb célcsoportjai a közép- és felsőfokú oktatásban résztvevök, a munkanélküliek, valamint az idősebb korosztályok tartoznak. A programok többsége a az annak bázisul szolgáló nagy- és közép centrumokat érinti a régióban. A szak- és átképzésre vonatkozó program azonban a régió egészét érinti.

C. A térség gazdasági bázisa kedvező adottságokkal rendelkezik, így fejlesztésének elsỏdleges iránya, annak miliỏjének megújitása, innovációorientált átalakítása. Célszerủ a területfejlesztés eszközeivel hozzájárulni, hogy a kialakuló gazdasági klaszterek egyrészt telephelyi és müködési feltételei javuljanak, amelyek elsődlegesen a gazdasági infrastruktúra korszerúsitését, új intézményeinek megteremtését feltételezik. Másrészt a térségben rendelkezésre álló sokoldalú és- szintủ szellemi kapacitások összehangolt fejlesztésével hozzá lehet járulni az új együttmüködések kereteinek szélesítéséhez. Ezen kẻt célcsoport alapján az intraregionális piac szélesedik, bövülnek a telephelyi tényezök, amelyek aztán a gazdasági bázis kedvezőbb megtelepedési és müködési körülményeit biztosítják. 
A legfontosabb problémák és szükségletek az alábbiakban összegezhetök:

C1. A térségben a gazdasági potenciál jelentős infrastrukturális bázissal rendelkezik, aminek az állapota leromlott és csak jelentős átalakitásokkal képes fogadni az új technológiákat, illetve az új szervezeti formákat. Nem alakultak ki a térségben a belsö piac szervezö rendszerei, a gazdasági egységek nem rendelkeznek információval sem a fejlesztésekröl, sem a szállítási, értékesítési kapcsolatokról, így nem járulnak hozzá a klaszterképződéshez. A telephelyi kínálat ugyan sokszínü a térségben, de nem koordinált, így a potenciális befektetök nem ismerik az adottságokat, a kínálatot, sőt a versenyhelyzet miatt számos település, térség ellenérdekeltséget képvisel.

C2. A térségben mind a népesség iskolázottsága, mind a különféle szintü oktatási egységek színvonala megteremti a lehetöségét annak, hogy még képzettebb, sokoldalú munkaerő álljon rendelkezésre, amely képes a különféle szintü innovációs folyamatok vezérlésére. Már a középtáv végére lényegében kimerülnek a fejlesztés mennyiségi feltételei (telephely kínálat, munkaerö), így újabb belső forrásokat kell aktivizálni, ezek közül viszonylag kisebb ráfordításokkal a szellemi erőforrások adottak a térségben.

D. A szükségletek alapján meghatározható föbb célok a következök:

- Gazdasági infrastruktúra fejlesztése (1.1. program)

$\Rightarrow \quad$ Ipari parkok, szolgáltatási övezetek összehangolt fejlesztése.

(1.1.1. program)

$\Rightarrow$ A kis- és középvállalkozások együttes fejlesztése (1.1.2. program)

$\Rightarrow$ A szállítási kapcsolatok és erőforrás feltárás, telephelymarketing (1.1.3. program)

- A szellemi eröforrások felkészítése (1.2. program)

$\Rightarrow$ A felsőoktatási bázis integrációja (1.2.1. program)

$\Rightarrow$ A kutatási-fejlesztési centrumok megerősítése (1.2.2. program)

$\Rightarrow$ A szakképzés, az át- és továbbképzés koordinálása (1.2.3. program)

E. A fenti célok megvalósitása érdekében javasolt fóbb intézkedések a következök:

Gazdasági infrastruktüra fejlesztése területén:

\subsection{1. program}

A térség több centrumában megkezdődött és tervezés alatt áll az ipari parkok és zónák kialakítása, célszerủ ezek fejlesztését összehangolni, a nagyobb központok között a lehetséges specializációkat meghatározni. A határmenti térségekben vállalkozási övezetek létesítése hozzájárulhat a jelentkező előnyök jobb kihasználásához, a közeli gazdasági csomópontok hatásainak jobb érvényesítéséhez. 


\subsection{2. program}

A térség kis- és középvállalkozásainak egymás közötti intraregionális kapcsolatai gyengék, esetiek, hasonlóan nincs kialakult rendszere annak, hogy ezek a gazdasági egységek jobban megismerjék a térségi adottságokat, erőforrásokat. Célszerü koordinálni és segíteni ezen egyre fontosabb piaci szereplöket a regionális szintü egymásra találásában, a kölcsönös szállítási kapcsolatokat ismertető információs rendszerek létrehozásával, a különféle vállalkozástámogató intézmények tevékenységeinek megismertetésével.

\subsection{3. program}

A gazdasági szereplök különféle szintjei elött nem ismert a térségben müködö egységek tevékenysége, a rendelkezésre álló kapacitások, a telephelyi kínálat, a kooperációs lehetőségek. Mindezek szervezettebbé tétele közös információs rendszerek (kamarák) kialakításával jelentősen növeli a regionális együttműködéseket. Fontos eleme az intraregionális gazdasági egyuittmüködéseknek a térség átgondolt telephely-marketingiének a kialakítása, ami a későbbi térségmarketinget is segitheti, ennek eszközei a telephelykinált egységes feltérképezése, annak nemzetközi kiajánlása (Internet), vásárkatalógus, térségismertetés, bemutatás.

\section{A szellemi eröforrások felkészitése területén:}

\subsection{1. program}

A térség talán az egyetlen régiója az országnak, ahol szinte mindegyik nagyközpontban, sőt a szubcentrumok közül is többen vagy nagy hagyományokkal rendelkezö, vagy az elmúlt években rendkívül dinamikusan fejlődő felsőoktatási bázis alakult ki. Jelenleg az együttmüködés - jobb esetekben - a városokon belül valósul meg, miközben párhuzamos fejlesztések és tervek kerülnek napvilágra. A térség esélyeit csak azzal lehet növelni, ha megkezdődik a tudatos, célirányos egyưttmúkődés a térségben és két-három egyetemi központ szerveződik meg (Veszprém, Sopron, Györ).

\subsection{2. program}

A rendelkezésre álló gazdasági potenciáltól alapvetően elmarad a térségben a $\mathrm{K}+\mathrm{F}$ kapacitások mértéke. Legalább mindegyik egyetemi centrumba szükséges egy-egy innovációs centrum telepitése, illetve az azzal nem rendelkező nagyvárosba technológia-transzfer centrumok (irodák) létesitése, amelyeknek a regionális szintủ összeköttetését szorgalmazni érdemes.

\subsection{3. program}

Jelentős erőforrásokat kötnek le a szakképzési programok, hasonlóan rendkívül bőséges az át- és továbbképzési kínálat. Célszerü ezeket határozottabban a térség kialakuló gazdasági klasztereihez alakítani, közöttük a koordinációt megvalósítani, a felesleges párhuzamok mérséklésével, illetve speciális, koncentrált programok beindításával, amelyek támaszkodhatnának a felsőoktatási és $\mathrm{K}+\mathrm{F}$ bázisra. 
F. A javasolt eredménymutatók az alábbiak:

- a beruházások aránya

- ipari parkra, vállalkozói övezetre fordított beruházási források

- a létrehozott új munkahelyek száma

- ipari parkban, vállalkozói övezetben létesült új munkahelyek száma

- tudásigényes (high-tech) iparágakhoz kapcsolódó munkahelyek száma

- a $\mathrm{K}+\mathrm{F}$ szervezetek száma

- a $\mathrm{K}+\mathrm{F}$ szervezetekben foglalkoztatottak száma

- új exporttermékek száma

- a termelésben alkalmazott megyei újitások száma

- a vállalkozások versenyképessége hazai és nemzetközi összevetésben (az export részaránya a nettó termelési értékben)

- a megyén belüli üzleti-termelési kooperációk száma (és értéke)

- a nyelvvizsgával rendelkezők száma

- a nem a megyében tanuló, de a megyében lakó felsőfokú oktatásban részesülö hallgatók száma, arányuk az összes megyében lakó hallgatók között

- a felsőfokú oktatási intézményekben tanulók száma és szakonkénti aránya

- a termelésben alkalmazott, a megye felsőfokú oktatási intézményeiben kidolgozott újítások száma

- az átképzésben részvevő munkanélküliek száma

- az átképzést követö egy éven belül, az új képesítésnek megfelelö munkát vállaló munkanélküliek száma

G. A programok koordinálását az 1.1.1., az 1.1.3. és az 1.2.2. program esetében a Regionális Fejlesztési Tanács, az 1.1.1. és az 1.1.2. program esetében a megyei Ipar és Kereskedelmi Kamarák, az 1.1.2. program esetében a Magyar Vállalkozásfejlesztési Alapitvány, az 1.2.3. esetében a megyei területfejlesztési tanácsok, valamint az 1.2.2. program esetében az oktatási tárca végzi. Az egyes programokban együttmúködö szervezeteket a 1. táblázat, a lehetséges finanszírozókat a 2. táblázat tartalmazza.

H. A prioritás kapcsolata más programokkal:

H1. Az egyes programok kapcsolódását a régió stratégia más prioritásaihoz a 5. ábra mutatja be.

H2. A kormány modernizációs programja "Az ezredforduló iparpolitikája" c. $\mathrm{X}$. fejezete megfogalmaz a gazdasági szerkezet és környezet fejlesztésére vonatkozó tételeket is. Várhatóan a kormányprogram szintjére emelkedik a modernizációt és szerkezetváltást segítő intézmények között egy ipari parkok hálózatát támogató program. Ez már az 1996. évi gazdaságfejlesztési célelőirányzat pályázati kírása keretében elindított progranként kezelhetö.

A kormány modernizációs programja a hazai modernizáció "húzóágazataként" kezeli a humán eróforrásokat. Két programpont (VI. és VII. fejezet) is ennek 
területnek a fejlesztésével foglalkozik. Különös hangsúlyt kap a középfokú- és a felsőfokú oktatás egymásrautaltsága. A demográfiai csúcsból kifutó korosztályok számára a pályakezdö munkanélküli helyzettel szemben alternatívát jelent a továbbtanulás. Ugyanakkor a következö, kisebb létszámú korosztályok esetében a középiskolából kikerülöknek mind magasabb arányban kell megfelelnie a felsöfokú oktatás, de legalább az ún. posztszekunderi képzés követelményeinek. Az oktatási tárca külön forrásokkal ösztönzi a felsöoktatási egységek integrációját.

H3. Mind a gazdasági infrastruktúra, mind a humán erőforrások fejlesztése számos ponton kapcsolódik az 1995-1999-re szóló PHARE CBC programhoz. Az előbbi elsösorban a No M31 és az No M41 jelü programcsomaggal, az oktatás pedig a No M42 jelú célkitüzéssel cseng össze. Konkrét projektek fogalmazódhatnak meg iskolák partnerkapcsolatára, oktatói és hallgatói cseréjére, nyelvtanításta, közös kutatásokra, valamint hálózatépítésre. Mindkét stratégiai program támaszkodhat világbanki hitelprogramokra, valamint a PHARE speciális alprogramjaira (pl. a kis- és középvállalkozások a JOPP-ra, míg az oktatás a TEMPUS-ra és a FEFA-ra).

\section{PRIORITAS: A MULTI- ÉS INTRAREGIONÁLIS KOHÉZIÓ ERŐSÍTÉSE}

A. A regionális kohézió erősítése az Északnyugat-Dunántúl megyéinek régióvá szervezését segítő prioritás. Ez a stratégiai célkitủzés horizontális jellegü: a javasolt intézkedések a megye gazdaságának valamennyi szektorában kifejtik hatásukat, de jelentős befolyással lesznek a településhálózatra és a társadalmi tényezőkre is. Ugyanakkor megfelelő alapot biztosít a határon átnyúló kapcsolatok elmélyítésére.

B. A programok célcsoportjába a gazdasági és társadalmi szféra valamennyi eleme beletartozik, döntỏen azonban a megyehatárok és az országhatár mentén elhelyezkedö önkormányzatok, vállalkozások, non-profit szervezetek, valamint térségfejlesztési társulások alkotják azt. Az intézkedések egy része a regionális együttmüködés intézményrendszerének kialakítását segíti, másik része pedig a már meglévő, illetve potenciális kialakuló kistérségi és települési együttmüködések fejlesztésére irányul. Ugyanakkor szerepet vállal abban is, hogy a régión belül és kívül elhelyezkedö nagyközpontok közötti kapcsolat erösödjék.

C. Az országban egyedül ebben a térségben indultak meg közel tíz esztendeje a tudatosan szervezett országhatár menti együttmüködések (osztrák-magyar határ menti kapcsolatok, illetve ezekre alapozva az INTERREG II. - PHARE CBC program 1996-1999). Ezeknek a multiregionális kapcsolatrendszereknek már számos eredménye van, ám a jövőben az egyes mezorégiókban már új 
együttmüködési formákra van szükség. A térségi belső kohézió gyenge, erőtlen, ami abból is következik, hogy elavultak az interregionális közlekedési kapcsolatok, miközben egyáltalán nem fejlödtek az interregionális hálózatok, sőt azok több esetben egyenesen akadályozzák a regionális szintü kapcsolatokat.

A legfontosabb problémák és szükségletek az alábbiakban összegezhetök:

Cl. Északnyugat-Dunántúl több mint 400 km-es országhatár szakasszal rendelkezik, amely részben történelmi régiókat választ el, illetve már napjainkban is egyre bővülő dimenziókban érvényesülnek a határgazdaság kedvező adottságai. Az országhatár menti kapcsolatok a régiófejlesztés meghatározó része, hiszen egyre több tevékenységet kell bekapcsolni az itt jelentkező lehetőségekbe, s ezáltal egyre nagyobb térségek ráfüződését kell biztosítani, hogy minél jobban "helyzetbe kerüljenek", minél sokoldalúbban megkezdődjön a külső és belső integrációjuk.

C2. A térség belső kohéziója napjainkban nem számottevö, így annak alakítását két metszetben kell megkezdeni. Az egyik a kibontakozó fejlódési (innovációs) zónák, övezetek ${ }^{8}$ összetartozását, kapcsolatait közvetítő közlekedési és kommunikációs hálózatok fejlesztésével, amelyek aztán a térség nemzetközi összeköttetéseinek szélesítéséhez is hozzájárulnak. A másik a régióépítés intézményrendszerével, ami tartalmazza a regionális fejlesztési tanács létrehozását, a régióra vonatkozó fejlesztési koncepció kidolgozását, a térségi médiák müködtetését (regionális rádió és televízió).

D. A szükségletek alapján meghatározható fóbb célok a következők:

- Országhatár menti együttmúködések fejlesztése (2.1.program)

$\Rightarrow$ Eurorégiók kialakítása (2.1.1. program)

$\Rightarrow \quad$ Határmenti kistérségi és települési együttmüködések (2.1.2. program)

- Régióépités (2.2. program)

$\Rightarrow$ Interregionális közlekedési hálózat fejlesztése (2.2.1. program)

$\Rightarrow$ Regionális intézményrendszer kialakítása (2.2.2. program)

E. A fenti célok megvalósítása érdekében javasolt föbb intézkedések a következök:

Az országhatár menti eguüttmüködések fejlesztése területén:

\subsubsection{Program}

Középtávon ki kell alakitani - éppen az egész térség tartós megújitása miatt - a Bécs-Pozsony-Györ-Sopron/Felsö-Pannónia eurorégiót, annak szervezeti, intézményi rendszerét. Hasonlóan érdemes elökészíteni és hosszabb távon létrehozni a Szombathely-Graz-Maribor-Zalaegerszeg hármashatár együttmüködést. 


\subsubsection{Program}

A nagytérségi regionális egyuittmüködésekhez kapcsolódnak a határ menti kistérségi és település szintủ kooperációk, amikhez középtávon nemcsak az új határátkelők megnyitása adhat lendületet, hanem a közlekedési kapcsolataik megújitása, feltártságuk növelése is. Célszerú támogatni minden olyan akciót, ami ezen viszonylatokban az infrastrukturális egybefüzéseket segitik elö, hiszen ezáltal a térségek megbomlott egysége fokozatosan újraszerveződik. Az országhatáron túli kapcsolatok mellett ugyanolyan érdekeltséggel szükséges foglalkozni a szomszédos megyékkel formálódó kapcsolatokkal, egyben az észak(nyugat)-dunántúli régió kialakításával. A regionális dimenzió az EU csatlakozás után a tervezés és a források elosztásának szințe lesz, így nem elhanyagolható, hogy a megye milyen pozíciót teremt meg a szerveződő régióban. Emellett szükséges a megyehatár menti térségek együttes fejlesztése, a régió érdekeinek különbözö szintủ (politikai, gazdasági) képviselete, a nemzetközi források (INTERREG Il - PHARE CBC) koordinált igénylése és felhasználása.

\section{A régióépités területén:}

\subsubsection{Program}

A térség együttes érdeke, hogy éppen a gazdasági szereplők élénkítése és a nemzetközi hálózatokba való jobb bekapcsolódása miatt, minél sokszínúbbé váljanak a belső közlekedési kapcsolatok. Átfogó programot kell kidolgozni az észak-déli összeköttetések megújitására (Győr-Veszprém, Györ-Pápa-DevecserTapolca, Rajka-Csorna-Szombathely-Rédics), s a nemzetközi relációkat is megjelenítỏ nyugat-keleti viszonylatok radikális korszerúsítésére (85-ös út, 8-as út, M7-es a határig, Szombathely-Celldömölk-Pápa-Veszprémvarsány-Kisbér). A hálózati rendszeren belül a munkamegosztás is jelentős, hiszen a közút fejlesztés mellett a vasúthálózat regionális gerinceinek korszerüsitése szükséges (Szombathely-Székesfehérvár vonal villamositása), illetve a hiányzó - felszámolt nemzetközi kapcsolatainak létrehozása (Szombathely-Oberwarth). Megoldást kell találni a regionális repülöterek kérdésében is, nélkülözhetetlen a logisztikai központok alapjainak lerakása, de a turizmushoz kapcsolódó térségi kerékpárutak fejlesztésében sem lehet várakozni.

\subsubsection{Program}

A régió épitésének egyik fontos eszköze a térségi folyamatokat szervezö, bonyolító intézményrendszer müködtetése. A program megfelelö alapot kínál arra, hogy éppen a felállítandó regionális fejlesztési tanács keretén belül létrejöjjön a térségfejlesztés menedzsmentje. Döntỏ eleme a régió alakításának, hogy folyamatosan formálódjon annak tudata, egyes elemei, alkotórészei a területfejlesztés szereplöinek gondolkodásában megjelenjenek, azok a napi tennivalói között helyet kapjanak. Célszerủ megerősíteni a térségben a regionális programokat sugárzó televízió és rádió múködését, azok fejlesztéséhez hozzájárulni, hiszen ezen két média sokat tehet a régió építésében. Kívánatos a régió egészére egységes marketing koncepciót kidolgozni, amiben ugyan jelen vannak az egyes alkotó megyék önálló karakterrel, de mindezek mégis sajátos területi egységet sugallnak, ahol a fejlődés dinamikus, a 
gazdasági és társadalmi folyamatok megújitása gyorsabb. Szükségesnek tartjuk, hogy térségi szinten kezdödjenek meg a különféle politikai, érdekképviseleti, de közigazgatási egységek, söt non-profit szervezetek kapcsolat felvételei, hiszen ezen szféra már a térségi gondolkodás terjesztésével sokat tehet a regionális szerveződés érdekében.

F. A javasolt eredménymutatók az alábbiak:

- Bécs-Pozsony-Győr-Sopron/Felső-Pannónia térség potenciális eurorégió intézményi rendszerének kiépítése

- a regionális és szektorális fejlesztési lehetöségeket bemutató tanulmányok száma

- a határterületre elkészített közös tervek

- a határon átnyúló, hatékonyan múködő információs és monitoring rendszer(ek)

- a határon átnyúló üzleti-termelési kooperációk száma (és értéke)

- a határon átnyúló technológiai és know-how transzferek száma (és értéke)

- a határon átnyúló $\mathrm{K}+\mathrm{F}$ kooperációk száma (és értéke)

- közös turisztikai programok turisztikai marketing

- a határon átnyúló környezetvédelmi kutatások és tudományos programok száma

- a határon átnyúló természetvédelmi/nemzeti park terület nagysága. intézménye

- a határon átnyúló oktatási csereprogramokon résztvett tanulók és oktatók száma

- közösen kialakított tantervek és training programok száma

- határon átnyúló munkaerőpiaci kooperációk száma

- a szomszédos kultúra megismertetését szolgáló rendezvények száma

- határon átnyúló munkaerôkoordináció, ingázó munkavállalók száma

- a megye városai elérhetóségi idejének csökkentése

- úthálózat fejlesztésére fordított erőforrások (reálértéke)

- telefon ellátottság

- az INTERNET szolgáltatásokat igénybe vevő vállalkozások száma

- infrastrukturális ellátási mutatók javulása

- az Észak(-nyugat)-dunántúli Regionális Fejlesztési Tanács (ÉDRFT)megalakulása

- az ÉDRFT által létrehozott közalapítvány és annak összege

- az ÉDRFT és a közalapítvány által indított és koordinált programok száma

- az ÉDRFT által koordinált fejlesztések összértéke, a mobilizált források nagysága

G. A programok koordinálását a határmenti együttmüködések esetében az érintett megyei önkormányzatok, míg a régióépités programjait a Regionális Fejlesztési Tanács végzi. Az egyes programokban együittmúködő szervezeteket az 1. táblázat, a lehetséges finanszírozókat a 2. táblázat tartalmazza.

H. A prioritás kapcsolata más programokkal:

H1. Az egyes programok kapcsolódását a megyei stratégia más prioritásaihoz a 5. ábra mutatja be.

H2. A kormány modernizációs programja egyben az országnak az EU-hoz való csatlakozásra való fölkészülés stratégiájaként is fölfogható. Ennek ellenére 
kevés figyelmet fordít az osztrák-magyar határ menti, vagyis egyben az EUmagyar határmenti kapcsolatok fejlesztésének.

A kormány modernizációs programja az infrastruktúra fejlesztését kiemelt célként kezeli (1X. fejezet). Ezen belül a kommunikáció és a közlekedési kapcsolatok erősítését a modernizáció alappilléreinek tekinti. Országos koncepció van logisztikai központok kiépitésére, melyben Győrbe is lehetséges helyszínként szerepel.

Az induló programokhoz pályázati források állnak rendelkezésre a különbözỏ tárcáknál lévö infrastrukturális fejlesztéseket szolgáló célelöirányzatból.

H3. PHARE CBC program egésze a határmenti, pontosabban a határon átnyúló kapcsolatok fejlesztésére irányul. Ezen belül a 3.1. program a No M11 jelü célkitủzéseinek keretei közé sorolható be, amelyben konkrét projekt célként a három országhatár menti megye által határolt térség fejlesztési koncepciójának és rendezési tervének kidolgozása, kitekintve Bécs-Pozsony-Györ potenciális eurorégió kialakítási körülményeire is. A közlekedési infrastruktúra fejlesztést a No M21-es jelü programcsomag segíti a PHARE CBC-n belül.

\section{PRIORITÁS: A BELSŐ PERIFÉRIÁK AKTIVIZÁLÁSA}

A. A belsỏ perifériák aktivizálásának prioritása átfogó jellegủ, mely nem a gazdaság egyetlen szektorára, s nem is kizárólag a gazdaságra koncentrál. A megvalósuló programok közvetlenül vagy közvetve a megye gazdaságitársadalmi életének szinte valamennyi területét befolyásolják.

B. A programok célcsoportját a gazdaság valamennyi szereplöje képezi, a vállalkozások ugyanúgy, mint az önkormányzatok, a háztartások és a nonprofit szervezetek a régió kedvezőtlen társadalmi-gazdasági mutatókkal rendelkező belső perifériáin.

C. A térségben a megyehatár menti, centrumhiányos övezetek belső perifériát alkotnak, azaz kapcsolódási irányuk egyoldalú vagy erősen megosztott, gazdasági szerkezetük kiszolgáló jellegú (pl. alapvetően a bérmunka jellemzi, a vállalkozások száma elenyészó), felvevő piacuk nem jelentős, a népesség elöregedett, az infrastrukturális felszereltség hiányos. Ugyanakkor a természeti környezet gazdag, a népesség vendégszerető, s számos eddig még nem aktivizált helyi eröforrással rendelkeznek (pl. termelési hagyományok, termálvízkészlet stb.), így egy mérsékelt megújitási folyamat feltételei adottak. Ezen fejlesztési prioritásnak a része az átfogó kistérségi programok kidolgozása, a szükséges infrastrukturális hálózatok kiépitése", illetve speciális kistérségi fejlesztési tanácsadás (menedzsment) intézményẻnek a felállitása. 
A legfontosabb problémák és szükségletek az alábbiakban összegezhetök:

C1. A térségben nagy számban szervezödő kistérségi szövetségek lehetőséget kínálnak a területfejlesztéshez, annak is az alulról épitkezö rendszereinek a kidolgozásához.

C2. A térségen belül napjainkban és középtávon is az intraregionális közlekedési kapcsolatok azok, amelyek az együttélést akadályozzák. A hálózatokban az észak-déli összeköttetések ugyan megtalálhatók, de azok minősége gyenge, számos esetben terhelésük nagy, ugyanakkor nem tárják fel az egész régiót, nem teszik lehetővé, hogy a nagytérségi és térségi szervezö központok gyorsan elérhetök legyenek. Hasonló a helyzet a nyugat-keleti kapcsolatokkal, azzal a különbséggel, hogy ezeknek már interregionális funkcióik is vannak, így megújitásuk nemcsak térségi, hanem nemzetgazdasági érdek is. Több közlekedési ágazatban és tevékenységben térségi szinten egyedi kezdeményezések vannak (regionális repülötér létesítése; Sárbogárd, GyörPér, kerékpárutak; országhatár menti hálózat, a Balaton megközelítése, kistérségi hálózatok; településközi kapcsolatok kiépitése stb.).

C3. A térségben, föleg a megyehatár menti zónákban a települési infrastruktúra több szektora fejletlen, jóval alacsonyabb, mint a nemzeti és a térségi átlag. Kimondottan alacsony az ellátottsági szint kommunikációs (telefon) infrastruktúrában és csatornázottságban, ezek fejlesztése csak térségi össze fogással lehetséges.

D. A szükségletek alapján meghatározható föbb célok a következök:

- Kistérségi programok kidolgozása (3.1. program)

- Intraregionális közlekedési kapcsolatok megújítása (3.2. program)

- Település infrastruktúra mennyiségi és minöségi növelése (3.3. program)

E. A fenti célok megvalósítása érdekében javasolt föbb intézkedések a következök:

\subsection{Program}

Ösztönözni kell föleg azon kistérségi programok kidolgozását, amelyek a megyehatár mentén húzódó településközi együttmüködéseket célozzák meg. Térségi jellege éppen ezen zónáknak lehet, miközben a koordinált fejlesztésekkel bővíthetők az eröforrások, gyarapodnak az együttélés terei. Ajánlatos továbbá regionális szinten összevetni a különféle kistérségi programokat, azokat igazítani az Északnyugat-Dunántúl egésze fejlesztéséhez, keresni a kapcsolódási pontokat, a közös megújitási irányokat, s egyben a szükségszerü összhangot. 


\subsection{Program}

Célszerủ áttekinteni és térségi szinten koordinálni a már kidolgozott, illetve az ezután kidolgozandó fejlesztési elképzeléseket, hogy a kapcsolódási pontok egyértelmüek legyenek, ugyanakkor az erőforrások koordinált felhasználása megtörténjen. Fontos regionális szervezó funkciónak tartjuk, hogy a térség nagyközpontjainak a tömegközlekedési eszközökkel történö megközelitése kiegyensúlyozott legyen, azok egymással kapcsolatban álljanak, s ezáltal is megtörténjen a szükebb, vagy tágabb vonzáskörzetük felfüzése. Kiemelt feladatként kell kezelni a Vas-Veszprém-Györ-Moson-Sopron megyék hármashatár térségében lévő területek keresztirányú feltárását (Rajka-Csorna-Pápa-Devecser-Tapolca, illetve Szombathely-Celldömölk-Pápa-Veszprémvarsány-Kisbér).

\subsection{Program}

Támogatandók mindazok a programok, amelyek a térségben, akár a megyehatárok mentén, akár az országhatárok mentén szerveződő infrastrukturális együttmúködésekre irányulnak. A megyéken belüli kistérségi szervezödések interregionális kapcsolatait is célszerü erösíteni, hiszen ezzel a regionális kapcsolatok új lehetőségei nyílnak meg.

F. A javasolt eredménymutatók az alábbiak:

- kistérségi társulásba belépett megyehatár menti települések aránya

- elkészült térségfejlesztési programok

- a térségfejlesztési program, térségmarketing hatására induló beruházások összege

- a régió nagyvárosi elérhetöségi idejének csökkenése

- úthálózat fejlesztésére fordított erőforrások (reálértéke)

- telefonellátottság

- infrastrukturális ellátás mutatóinak javulása

G. A programok koordinálását mindegyik alprogram esetében a regionális fejlesztési tanács végzi. Az egyes programokhoz források állnak rendelkezésére a decentralizált területfejlesztési alapból. Az egyes programokban együttmúködö szervezeteket a 1 . táblázat, a lehetséges finanszírozókat a 2. táblázat tartalmazza.

H. A prioritás kapcsolata más programokkal:

H1. Az egyes programok kapcsolódását a megyei stratégia más prioritásaihoz a 5. ábra mutatja be.

H2. A kormány modernizációs programja az infrastruktúra fejlesztését kiemelt célként kezeli. Ezen belül a kommunikáció és a közlekedési kapcsolatok erősitését a modernizáció alappilléreinek tekinti. Országos koncepció van logisztikai központok kiépitésére, melyben Györbe is lehetséges helyszínként szerepel. 
Valamennyi alprogram számára rendelkezésre áll megpályázható központi célelöirányzat.

H3. Ennek a prioritásnak a mindegyike közvetlenül bekapcsolható a PHARE CBC prioritás rendszerébe. A 3.1. a No M11, a 3.2. a No M21, a 3.3. program pedig a No M21 és a no M51 jelú célkitủzések keretei közé sorolható be.

\section{PRIORITÁS: A KÖRNYEZETI POTENCIÁL MEGÓVÁSA}

A. A megye jövőképe nem képzelhetỏ el a környezeti állapot javítása nélkül. Nem egy általános szlogenröl van szó, hanem arról, hogy bármelyik programpont csak akkor müködik, ha a megye környezeti állapota határozottan javul, egyáltalán teret nyer egy ökológia érzékeny szernléletmód (tervezés) és cselekvés (programok végrehajtása).

B. A programok célcsoportjai elsösorban a megye lakossága és a vállalkozások, közvetett módon pedig az ide látogató turisták. A környezetvédelmi koncepció megyei szintủ programot igényel, mig a természetvédelmi program inkább térségi programokra építhető.

C. A legfontosabb problémák és szükségletek az alábbiakban összegezhetök:

C1. A térségben a környezeti potenciálhoz a gazdasági bázis számos eleme (turisztika, nyersanyag-kitermelés) szervesen kapcsolódik, így az ökológiai állapot bármilyen változásának jól kimutatható gazdasági és egyben területfejlesztó hatása van. Ugyanakkor a térség ökopotenciálja olyan új kínálati elemeket is tartalmaz, amelyek iránt hosszabb távon számottevỏ hazai és külföldi kereslet jelentkezhet. A Balaton és a természetvédelem szempontjából védett térségek környezeti állapotának megóvása mellett, szükséges az ipari városok környezeti ártalmainak csökkentése, a nyersanyagtermelésböl következő területkárosítás felszámolása, de a határozott kơrnyezet-orientált fejlesztés alkalmazása a kistérségi programokban, ezzel a térségek ökológiai adottságainak széleskörủ megóvása.

A térségben a korábbi gazdálkodási formák következtében környezet szennyezési gócok keletkeztek (Várpalota, Ajka, Szigetköz, bányászati területek), amelyek felszámolása, vagy terhelési szintjének csökkentése a fejlesztés érdekében elengedhetetlen. A környezet szennyezés mérséklése lehetőséget kínál az ipari területek rehabilitációjához, azok új szempontok szerinti hasznosításához. Tỏbb gócterület megtisztítása, illetve az ottani környezeti rehabilitáció nem oldható meg sem helyi, sem térségi forrásból, így nélkülözhetetlen a nemzeti szintú támogatások igénylése.

C2. A térségben rendelkezésre állnak olyan természeti-táji adottságok, amelyeknek a gazdasági hasznosítása új lehetôségeket kínálhat a területfejlesztéshez. A természeti táj nyújtotta környezet a következő iđőszakban felértékelődik az életmód változásával, az életkơrülmények fokozatos átalakulásával. 
D. A szükségletek alapján meghatározható föbb célok a következök:

- A környezeti károk felszámolása és mérséklése (4.1. program)

- Az ökopotenciál feltárása és gazdasági aktivizálásához programok készítése (4.2. program)

E. A fenti célok megvalósítása érdekében javasolt föbb intézkedések a következők:

\subsection{Program}

A különféle fejlesztési programoknál igényes, kimondottan terület specifikus körmyezeti szabályozást kell alkalmazni, illetve meghatározni az ezredfordulóig a minimális környezetvédelmi programot (szennyvízhálózat, hulladék-elhelyezés, vízbázis védelme, szennyezett területek rehabilitációja).

\subsection{Program}

A régió bövelkedik természeti értékekben (Balaton, Bakony, Szigetköz, Fertö-tó, Örség stb., gazdag termálvíz készlet), szükségszerü növelni a védelemre szoruló területeket, miközben azok gazdasági hasznositását is keresni kell. Tudatosan készülni kell arra, hogy egyrészt kiajánlásra kerüljenek ezek az adottságok, másrészt pedig hásznosításukban a fenntartható fejlődés elvei érvényesüljenek. A vidékfejlesztésnél külön programokat célszerủ indítani a térség öko-potenciáljának hasznosítására.

F. A javasolt eredménymutatók az alábbiak:

- a közmủolló mértékének csökkentése

- a környezet minősége/szennyezettsége (emissziós és imissziós adatok)

- a környezet minőségét védő/javító beruházások mértéke

- a környezetbarát technológiákra fordított beruházások összege

- a bevezetett új környezetbarát módszerek, technológiák száma

- a természetvédelmi terület/nemzeti park területe

- a természetvédelmi/nemzeti park területen megvalósított projektek száma, értéke

- a természetvédelmi területek monitoring rendszerére jutó ráfordítások (reálértéke)

- a turisztikai lehetőségek ismerete a megyei és hazai turisztikai információs centrumokban a természetvédelmi a megyei területekről/nemzeti parkokról

- a turisztikai lehetőségek ismerete a határos országokban és az európai turisztikai információs centrumokban a megyei természetvédelmi területekről/nemzeti parkokról

G. A programok koordinálását az 4.1. program esetében a környezetvédelmi és területfejlesztési tárca, az 4.2. program esetében pedig a regionális fejlesztési tanács és a megyei területfejlesztési tanácsok. Az egyes programokban együttmüködő szervezeteket a $I$. táblázat, a lehetséges finanszírozókat a 2. táblázat tartalmazza. 
H. A prioritás kapcsolata más programokkal:

H1. Az egyes programok kapcsolódását a megyei stratégia más prioritásaihoz az 5. ábra mutatja be.

H2. A kormány modernizációs programja a környezet minöségének javítását kiemelt célként kezeli, amelyben elsőrendúnek tartja a szabályozás kérdését is. A szennyezett ipartelepek kármentesítésére és rehabilitációjára kormányprogram készültt.

H3. A PHARE CBC program kiemelt célként kezeli a környezet minöségének javítását a határmenti térségekben. A 4.2. program alapvetöen a No M52 jelü célkitủzések keretei között müködhet (pl. Fertö-tavi Nemzeti Park és a soproni hegyvidék fejlesztése), de a No M32 célkitüzései közé is besorolható (a nemzeti parkok turisztikai célú fejlesztése, marketingjének erósítése).

\section{Ajánlások a Kormányzati kompetenciába tartozó célokra, azok tartalmára}

A régió fejlesztésének alapvető mozgatója a helyi, a kistérségi és a megyei kezdeményezések, amelyek egyrészt tükrözik a régióban megindult gazdasági és társadalmi folyamatokat, s mindezekhez a helyi erőforrások maximális aktivizálását rendelik. Vannak azonban olyan fejlesztések, amelyek túllépnek a térségi szereplők kompetenciáján részben az erőforrások, részben pedig a megvalósítás törvényi lehetőségei miatt. Szükséges tehát felhivni a Kormányzat figyelmét a fejlesztési stratégiában azokra az prioritásokra és programokra, amelyekhez nélkülözhetetlen a Kormányzati beavatkozás, részvétel.

$\mathrm{Az}$ ajánlásokat objektív szakmai érvek támasztják alá, valamint egyedi szempontok és a térségi igények egészítik ki.

\subsection{Bécs-Pozsony-Györ-Sopron/Felsö-Pannónia potenciális eurorégió intézményi keretei}

A fejlesztési stratégia súlyponti eleme, hogy minél elöbb intézményesüljön az egyre látványosabban formálódó Bécs-Pozsony-Győr-Sopron együttmüködési övezet. A térség kompetenciáját jelentősen meghaladja ennek a multiregionális szintü egyủttmüködésnek a szervezése, az ahhoz szükséges jogi és egyéb feltételek alakítása. Az intézményesült együttmúködés alapvető lépés lehet az integrációs folyamatban, ugyanakkor példaértékú modellként szolgálhat más országhatár menti együttmúködésekhez is.

Ehhez a kérdéskörhöz tartozik a határ menti vállalkozási övezetek létesítésének szabályozása és annak megvalósulásának részbeni támogatása. Szentgotthárd, Sopron és Mosonmagyaróvár térségében adottak a feltételek arra, hogy speciális 
funkciókat megvalósító vállalkozói övezet jöjjön létre, napjainkban a helyi kezdeményezéseket a szabályozási hiányosságok akadályozzák.

Az INTERREG II. - PHARE CBC program támogatásai csak abban az esetben lehívhatók, ha a projektek saját, illetve nemzeti forrással is rendelkeznek. A kormányzati szintnek a bruttó programköltségvetés $20 \%$-át kell biztosítania az ötéves indikatív program időszakában. Ez évi mintegy 2 MECU kormányzati forrás rendelkezésre állását igényeli.

A fejlesztési stratégia egy potenciális négymegyés Északnyugat-dunántúli régióra készült. Szükséges a kormányzati támogatás annak érdekében, hogy - abban az esetben, ha a PHARE CBC programot megújítanák az ezredfordulón, akkor Veszprém megye, mint ennek a régiónak a része, szintén a kedvezményezettje lehessen ennek a programnak.

\subsection{Kiemelt közlekedési rendszerek fejlesztésében való aktiv szerepvállalás}

A régió kohéziójának szük keresztmetszetét a közlekedési hálózat minöségi korlátai, valamint annak egyoldalú szerkezete jelenti. Ezen hálózati elemek korszerúsítése, így a 85-ös és 86-os utak átalakítása részben a térségen belüli kapcsolatok javitását, részben pedig az ország új tranzit szerepének, $s$ azzal együtt a megyei, de az egész észak-dunántúli gazdaság fejlesztését is szolgálják.

A megyében megkezdődött a közlekedési hálózat szerkezetének átalakítása, így a vízi- és légiközlekedés (Gönyü, Pér, Sármellék) regionális bázisainak kiépítése. Ezek a létesítmények tekintettel a jelentős térségszervezö funkcióikra, illetve a magas beruházási költségekre csak kormányzati támogatások mellett valósíthatók meg. A már polgári céllal hasznositható repterek sorába történỏ fölvételre megfontolandó a szentkirályszabadjai, valamint részleges polgári használattal a pápai reptér is.

Hasonlóan nem területi kompetencia a nemzetközi érintkezést, s ezzel a dinamikusan fejlődő határ menti kapcsolatokat szolgáló új határátkelőhelyek létesítése is, illetve a meglévők korszerüsitése, fogadóképességének növelése. Ugyanez vonatkozik a tervezett autópálya (8-as út Székesfehérvár és Veszprém között), a gyorsforgalmi út (85-ös, 86-os, S9-es, 8-as út Veszprémtöl), a VasVeszprém-Győr-Moson-Sopron megye hármashatár térségét föltáró keresztirányú föutak, valamint a vasút-korszerüsitésekre is (Szombathely-Székesfehérvár vonal villamosítása.

\subsection{Környezeti potenciál megóvása}

A régió környezete számos tényezöt tekintve fokozottan veszélyeztetett. A térségben a korábbi gazdálkodási formák következtében környezet szennyezési gócok keletkeztek (Várpalota, Ajka, Szigetköz, bányászati területek), amelyek felszámolása, vagy terhelési szintjének csökkentése a fejlesztés érdekében elengedhetetlen. A környezet szennyezés mérséklése lehetőséget kínál az ipari területek rehabilitációjához, azok új szempontok szerinti hasznositásához. Több gócterület megtisztítása, illetve az ottani környezeti rehabilitáció nem oldható meg 
Tér és Társadalom, 11. 1997. 1. 219-269. p.

sem helyi, sem térségi forrásból, így nélkülözhetetlen a nemzeti szintủ támogatások igénylése.

A Balaton, mint Európa legnagyobb édesvizi tava, nemcsak Veszprém megye, hanem Magyarország kiemelkedő természeti-turisztikai értéke. A tó környezeti terheléséből fakadó problémák kezelése, vonzerejének megtartása és fejlesztése térségi szinten valósítható meg. A Balatonra önálló fejlesztési koncepció készült. A Területfejlesztésröl és rendezésröl szóló törvény rendelkezik a Balatoni Regionális Fejlesztési Tanács létrehozásáról. Szükséges, hogy a Költségvetés - az eddigiekhez hasonlóan - önállóan kezelje a Balaton támogatását. Az erre a célra elkülönített központi forrásokat célszerủ a létrehozandó fejlesztési tanácshoz decentralizálni. A Duna értékeinek megörzése ugyancsak túlnő a helyi és térségi feladatokon. Ehhez jelentős hátteret biztosítana, ha a régió védett területei a Fertö-tavi Nemzeti Park mellett kibővülnének egy Dunamenti Nemzeti Parkkal.

\section{A stratégia érvényesitése és a monitoring}

\subsection{A területfejlesztés beavatkozási területei}

A fent meghatározott fejlesztési programok egy része a térség egészére, egyes elemei a kistérségekre szabottan jelennek meg, míg vannak részei, melyek a vonalas infrastruktúra fejlesztésére vonatkoznak, ezek többnyire még a megyéket is felfüzik. Az Országos Területfejlesztési Koncepció (OTK) irányelveiben foglaltak szerint a térségben $7+1$ térségtípust határoltunk le, ahol a fentebb bemutatott fejlesztési programok más és más szemléletủ, és léptékủ közelitésére van szükség.

A térségtípusok követik az Európai Unióban alkalmazott térségi elhatárolások alapelveit, hiszen a támogatási rendszereknek, a kezelési technikáknak és a fejlesztési megoldásoknak közelíteni kell az európai normákhoz. A kutatások eredményei szerint és ezen normák alapján a régió kistérségeinek besorolását mutatja a 6. ábra. A lehatárolt térségtípusok a következök:

- a gazdasági innováció pólusterulete,

- a gazdasági és jövedelemi színvonal szempontjából a térségi átlagtól elmaradott területek,

- az ipari szerkezet-átalakítás térsége,

- rurális (dominánsan mezőgazdasági) térség,

- munkanélkuliséggel küzdö térség,

- környezeti szempontból kiemelten kezelendỏ térség,

- határmenti térség, domináns kapcsolatokkal nem rendelkeznek,

- átmeneti, vegyes gazdaságú térség. 
6. ÁBRA

Az Északnyugat-Dunántúl kistérségeinek besorolása az Országos Területfejlesztési Koncepció szerint (Classification of the small regions of North-West Transdanubia by the National Regional

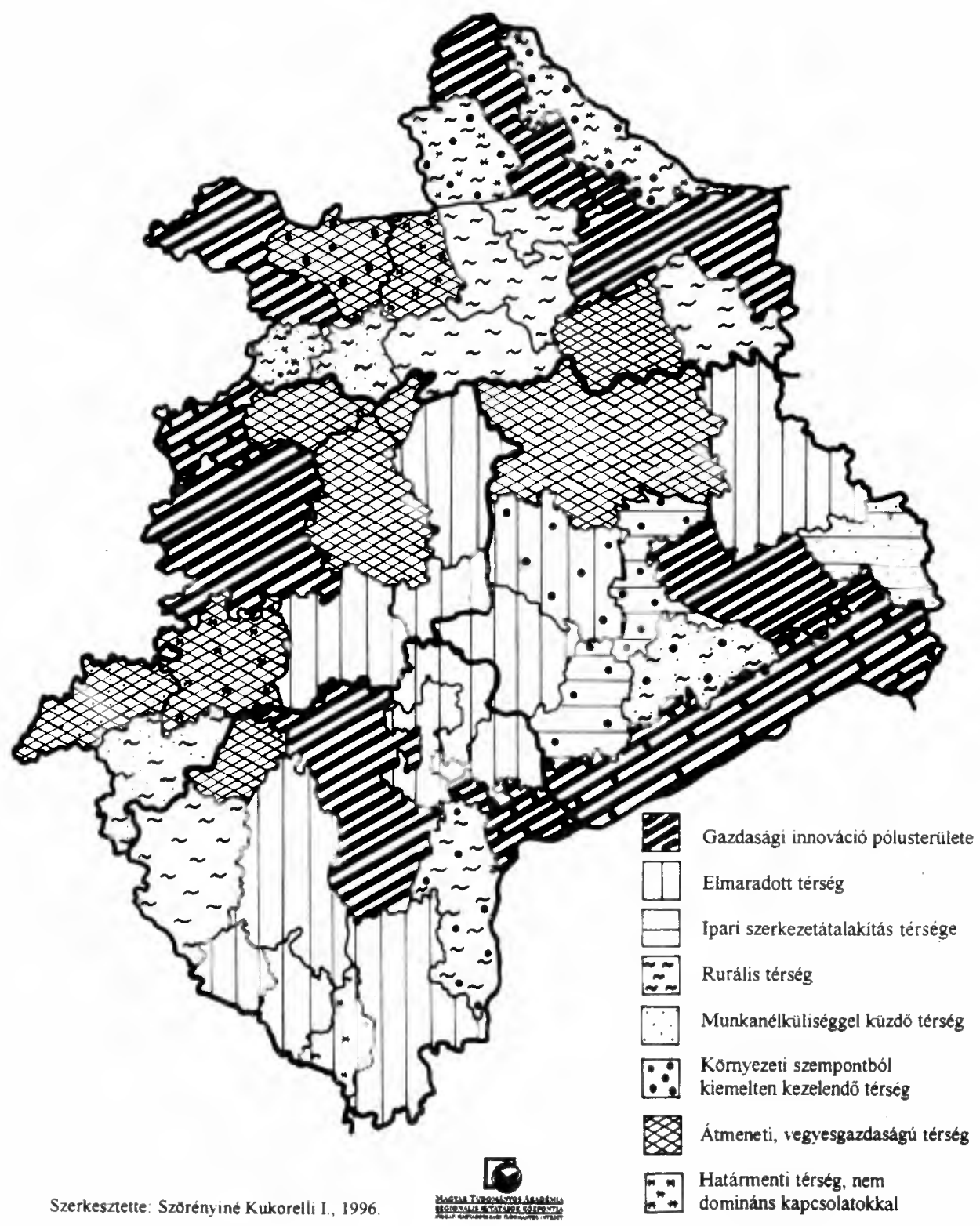


Az Országos Területfejlesztési Koncepció Irányelveit megalapozó tanulmány a 138 térséget besorolja a külonboozỏ térségtípusokba, osszesen 10 beavatkozási tipust határoz meg. A koncepcióban ÉszaknyugatDunántúl négy megyéjének körzetei hat típusba sorolódnak a különbözó szempontok szerint. GyôrMoson-Sopron, Vas és Zala megye egész területe a határmenti térség típusba tartozik, s ezen belül is azon altípusba, amelyre a INTERREG II. -PHARE CBC program kiterjed. A társadalmi-gazdasági szempontból elmaradott térségtípusba csupán a Vas megyei vasvári körzet, s a Zala megyei lenti-i, letenyei körzetek tartoznak. A kapuvári, a sümegi és a zalaszentgróti és lenti-i korzet a mezögazdasági (rurális) térség kategóriába tartozik. A magasan tartós munkanélküli körzetek típusába Sümeg és Letenye korzete tartozik. Györ-Moson-Sopron és Vas megyét érinti a környezeti szempontból kiemelten kezelendō típus, ahova a Feriō-Hanság térsége, a Köszeg-Hegyaljai Üdülőkörzet és Szigetköz tartozik, az utóbbi mint a Dunai Vizierömú projekt által érintett terület egyike. A 27 KSH körzet közül csupán 6 olyan körzetet emilit az anyag, mely valamely támogatásra javasolt. Tehát az ország egészét vizsgálva meglehetớsen homogénnek tünik az ország észak-nyugati része, hiszen 21 térség semmilyen támogatási típusba nem tartozik.

Tekintettel azonban a térség sokkal differenciáltabb térszerkezetére, továbbá a látványosan megindult kistérségi szerveződésekre, a stratégia készitése során 48 kistérséget vettünk alapul. Ezen kistérségek besorolását, mint a stratégia térségi szintủ beavatkozási területeit, az országosan alkalmazott térségtípusokba egyrészt a térségre vonatkozó mérőszámokkal való összevetés, másrészt a térségre végzett átfogó kutatásaink eredményei alapján határoztuk meg.

A beavatkozási területek rögzitésének előnye, hogy

$\Rightarrow \quad$ a térség egészének fejlesztésénél egyértelmủen alkalmazhatók az országos irányelvek és igények,

$\Rightarrow \quad$ a mikrotérségek fejlesztési pályáinál a nemzetközi és a hazai elvárások érvényesíthetök,

$\Rightarrow \quad$ a rendelkezésre álló források felhasználásának rangsorolása eldönthető,

$\Rightarrow \quad$ mérhetöek és összevethetök a fejlesztések hatásai.

\section{A gazdasági innováció pólusterületei a térségben:}

Gyơr, Sopron, Mosonmaguaróvár, Szombathely, Köszeg, Veszprém, Zalaegerszeg és térségük, valamint a Balaton-mente és Keszthely-Héviz kistérség.

A felsorolásból jól látszik, hogy a régió valamennyi megyeszékhelye és vonzáskörzete ebbe a típusba tartozik, azaz a megyék centruma, valamint a turizmus területén élénk vállalkozói aktivitást mutató Balaton part. E térségek három elkülöníthető területen koncentrálódnak, az ún. észak-nyugati innovációs tengely mentén, az osztrák határmenti sávban, $\mathrm{s}$ a régió déli részében Zalaegerszegtöl a Balaton parton át a régió határáig.

A fejlesztés föbb célkitüzései:

Ezeknek a központoknak nem a megújitása, hanem a gazdasági bázisaik innováció-orientált fejlesztése a kivánatos, illetve egyre határozottabb részvételük az európai városok munkamegosztásában, amit egyrészt a nemzetközi összeköttetéseik javításával, másrészt pedig a kibontakozó multiregionális együttmüködésekkel (eurorégió) lehet elérni. Ugyanakkor olyan településkörnyezet kialakitása is a fejlesztés célja, amely még vonzóbbá, sokoldalúbbá teszi a központokat. 
A térség esetében nem elhanyagolható az sem, hogy ezen centrumok intra- és interregionális összeköttetései, elérhetősége javuljon, hiszen a térségi, regionális szerepeiket csak ennek megfelelöen tudják gyakorolni. Végezetül kiemelendő kapcsolatuk a vonzáskörzettel, az agglomerációs területtel. Az együttmúködésen, a kölcsönös fưggésen, a rendszerek egybekapcsolásán alapuló fejlesztések képzelhetök csak el, miközben az egyedi sajátosságok éppen ezen térségekben is érvényre jutnak (Györ és Mosonmagyaróvár térségében az alakuló innovációs tengely, Sopronnál a határozott szerepvállalás a Bécsi agglomerációban, egyben Észak-Burgenland térségszervezésében; Szombathely és Köszeg esetében a látványosan formálódó település agglomeráció; Zalaegerszeg esetében a vonzáskörzet felértékelödése; a Balaton térségében és Veszprémben pedig a sajátos funkciókból következő tevékenység koncentrációk).

\section{A gazdasági és jövedelmi színvonal szempontjábỏl a térségi átlagtól elmaradott területek:}

Celldömölk. Jảnosháza, Vasvár. Letenye, Zalaszántó, Zalaszentgrót, Nagykanizsa, Sümeg és Zirc térsége, valamint ZalaKar, Somló-vidéke és BelsöGöcsej térségek.

A gazdaságilag, társadalmilag és infrastrukturális szempontból is elmaradott térségek markánsan két területen koncentrálódnak, s egyben regionális jelleget öltenek. Az egyik területi koncentráció a három megyehatár (Vas, Veszprém, Zala) találkozásánál jellemző. Közel azonos fejlettségüek, problémáik hasonlóak, hiszen valamennyi távol van a centrumtól, sajátságos belső perifériális helyzetben voltak és vannak ma is. Zirc és térsége szintén megyehatár menti fekvésü, de ettől a csoporttól elkülönülten fekszik.

Az ide tartozó többi kistérség Zala megye országhatármenti, vagy azzal közvetlen határos térségei, ahol korábban hosszú időn keresztül az országhatár jelentette az elzártságot, akadályozta a fejlődést és a megújítást. Valamennyi kistérségre jellemzó, hogy gazdasági bázisuk gyenge, többnyire depressziós, elmaradott, vagy alapvetöen hiányos infrastruktúrával rendelkezik, s a népesség erózió "mintaterületei". Mindemellett, vagy ebböl fakadóan térségszervező központjaik funkciói hiányosak, vagy sok esetben, mint térségszervező központok egyszerủen hiányoznak (Belső-Göcsej, ZalaKar, Zalaszántó kistérségek).

\section{A fejlesztés föbb célkitüzései:}

\& térségi fejlesztési programok összeállitása,

\ munkahelyteremtő vállalkozások telephelyi feltételeinek kialakítása és külső tökevonzás ösztönzése,

\ infrastrukturális-fejlesztés, illetve korszerüsités, amely hatékonyan segíti az átfogó mikrotérség fejlesztési cél megvalósitását (térségi együttműködések, települések infrastrukturális szintjének emelése), 
Tér és Társadalom, 11. 1997. 1. 219-269. p.

Az Északnyugat-Dunántúl területfejlesztési ... 261

\ a térségek belső fejlódési kezdeményezésének ösztönzése (helyi adottságokra épülő tevékenységek, turizmus fogadóképességének kiépítése, térségek ismertségének fokozása),

- oktatási és képzési programok,

- a centrumok szolgáltató funkcióinak erösítése,

- térségi fejlesztési programok összeállítása,

- munkahelyteremtő vállalkozások telephelyi feltételeinek kialakítása, és a kủlsö tökevonzás ösztönzése,

- infrastrukturális fejlesztés, illetve korszerüsítés, amely hatékonyan segíti a mikrotérség átfogó fejlesztési céljainak megvalósitását (térségi együttmüködések, települések infrastrukturális szintjének emelése),

- a térségek belső fejlödési kezdeményezésének ösztönzése (helyi adottságokra épülő tevékenységek, turizmus fogadóképességének kiépítése, térségek ismertségének fokozása),

- oktatási és képzési programok,

a centrumok szolgáltatási funkcióinak erősítése.

\section{Az ipari szerkezetátalakitás térségei: \\ Várpalota, Tapolca, Ajka és térségük tartoznak ebbe a típusba.}

Mindhárom a korábbiakban Közép-Dunántúli Iparvidékként emlegetett területhez tartoznak. A kedvező demográfiai tényezök, mint a fiatal korstruktúra, a már ebböl következő népességnövekedés a megújulást magában hordozza. Ugyanakkor a gazdaság válságba kerülése miatt felerősödött az elvándorlás, megnött a munkanélküliség. A három kistérség, illetve azok centrumaiban a gazdasági szerkezet átalakitása megkezdődött, részben helyi, részben pedig országos kezdeményezésre.

\section{A fejlesztés föbb célkitüzései:}

\ a termelő infrastruktúra fogadóképességének növelése (ipari parkok létesítése, ipari területek rehabilitációja),

- a centrumok közlekedési kapcsolatainak megújítása,

- a munkaerö átképzése az új tevékenységek ellátására,

- kis- és középvállalkozások beindítása, menedzselése,

- centrumok térségszervező szerepének fokozása, szolgáltatási funkcióik erösítése,

- környezeti terhelés mérséklése,

- környezeti állapot rehabilitációja.

A területfejlesztés eszközeivel csak a gazdasági szerkezet átalakításának feltételeit lehet megerősíteni, magának a szerkezetnek a megújitása már a gazdasági egységek kompetenciájába tartozik. 


\section{A rurális (mezögazdasági) térségek:}

Györ-Moson-Sopron megye nyolc térsége: Szigetköz, Mosoni-sík, Tóköz, Dél-Rábaköz, Sokoró, Alpokalja és a Kavicstakaró települései, és Csorna térsége. Vas megyében Örség, Veszprém megyében Balaton-felvidék (Nagyvázsony térsége). Zala megyében Göcsej-Örség-Hetés és Kis-Balaton térsége tartozik ebbe a tipusba.

Természetesen a legtőbb mezőgazdasági térséget a mezőgazdaságra oly alkalmas kisalföldi tájon találjuk. Főbb jellemzőjủk, hogy a mezőgazdaság a gazdaság meghatározó ága, mely vagy a nagyon kedvezỏ adottságokból, a fôld minóségébỏl adódik (Tókỏz, Dél-Rábaköz), vagy a magán és társas vállalkozások eredményes múkỏdéséból, magas aktivitási fokából (Balaton-felvidék, Örség).

\section{A fejlesztés főbb célkitüzései:}

- a mezőgazdasági tevékenység termékszerkezetének és fajtaválasztékának a piaci igényekhez jobban igazodó átalakítása (térségi agrárprogramok),

- a terület-felhasználás ökológiai és földrajzi feltételeinek megfeleló szerkezeti átalakítása, az adottságoknak megfelelö múvelési ág megválasztása,

- a kedvezőtlen termőhelyi adottságú térségekben a termelési árkiegészítés helyett környezetkímélö tájgondozási jövedelem - kiegészítỏ támogatás nyújtảsa,

¿ a városhiányos vagy gyenge városi funkciókkal ellátott terủleteken megfelelő centrumok kialakítása,

- az alacsony népsúrúségnek és a kis településeknek megfelelỏ ellátási formák kialakítása,

- a partnergazdaságokban a nem mezỏgazdasági, nem paraszti családokban a mezőgazdasági kiegészítő jövedelem megszerzési lehetőségeinek elősegítése,

\& a környezetkímélỏ mezőgazdasági technológiák elterjesztése,

- jövedelem kiegészítés címén a falusi turizmus beépülése a gazdaság szerkezetébe.

\section{Munkanélküliséggel küzdö térségek:}

Györ-Moson-Sopron és Vas megvében két-két térség tartozik ide: Alpokalja és Kavicstakaró települései, valamint Örség és Szentgotthárd térsége. Veszprém megvében szintén két kistérség: Balaton-felvidék és Vảrpalota térsége.

Sajătosságuk, hogy a munkanélküliség más terủleti problémákkal együtt van jelen (rurális, ipari szerkezet-átalakítás, környezeti feszủltségek), Várpalota térségét kivéve valamennyi távol esik a nagyobb városoktól, a jelentős munkaerőt foglalkoztató centrumoktól, csak Várpalota esetében magyarázhatjuk a magas munkanélküliséget az ipari válságtérséggel. Tehát a régióban a magas munkanélküliség a centrumoktól távol eső, elsősorban rurális, azaz vidéki munkanélküliséggel azonosítható. Ezért is fontos a gazdaságszerkezet bỏvítése, a turizmus és a szolgáltatói szféra erósítése, azaz kiegészitő tevékenységgel a foglalkoztatás bỏvítése, a jövedelem kiegészítése. 
Tér és Társadalom, 11. 1997. 1. 219-269. p.

A fejlesztés föbb területei:

A rurális, de munkanélküliséggel sújtott térségekben:

\ munkaerő képzési , átképzési programok,

- kisvállalkozások beindítása föleg a turizmus, szolgáltatás, vendéglátás területén,

tréning programok a turizmus területén,

- kis és középvállalkozások segítése,

a falusi turizmus feltételeinek támogatása.

Az ipari karakterü területeken (Várpalota, Szentgotthárd térsége):

- kialakításra kerüljenek a döntỏen munkaerőigényes ipari termelés feltételei (ipar fogadóképességének megteremtése),

- átképzési programok indítása,

- a térségi központok és telepuléseik közlekedési kapcsolatai javuljanak.

\section{Környezeti szempontból kiemelten kezelendö térségek:}

Györ-Moson-Sopron megyében: Szigetköz, Mosoni-sik(Hanság), Fertö-mente,

Veszprém megyében: Somló-körnvék, Ajka és Tapolca térsége, Balatonfelvidék és a Balaton-mente, Zala megyében Kis-Balaton térsége, és KeszthelyHéviz kistérség. Vas megyében Köszeg és térsége,

$\mathrm{Az}$ ide sorolt térségek két megközelítésből kerültek ebbe a típusba: a meglévő környezeti értékek megóvása, és a környezeti értékek helyreállítása. Mégis a környezetgazdálkodás érdekében egységes rendezést igényelnek, hiszen részben a kiemelkedő jelentőségủ természeti értékek védelme, részben a sokféle, eltérö környezet- és terulethasználati érdek összehangolása követeli meg a beavatkozást.

Ezen térségek más területi sajátosságokkal is rendelkeznek, így a megújitásuk súlypontja dominánsan a területi-gazdasági szerkezetük fejlesztésére irányul, de azok részeként vagy azokra építve a környezeti és természeti értékek megóvása, vagy helyreállítása szükséges, illetve olyan termelési struktúrák megtelepedésének támogatása, amelyek ezen értékekre épülnek, azok újszerü felhasználását teszik lehetővé.

VII. Határ menti térségek, amelyek nem rendelkeznek domináns kapcsolatokkal (pl. nagyforgalmú hatórátkelókkel) - a régióban az alábbiak:

\section{Szigetköz, Mosoni-sik, Alpokalja, Kapuvár térsége, Körmend térsége, Muramente.}

A határátkelöhely hiánya, vagy ideiglenes volta miatt a térségek a nyitott határral járó előnyöket nem élvezhették, nem épithették be gazdaságukba, a határátkelöhellyel rendelkezỏ térségekkel szemben hátrányuk nỏtt. 
A felsorolt térségek is már besorolódtak a fenti típusok valamelyikébe, azaz a területi-gazdasági szerkezet megújitásának egyes föbb típusaiba, de ezen fejlesztéseknél a határmenti fekvésböl származó adottságokat hangsúlyozottan figyelembe kell venni, s be kell épiteni a térségek fejlesztési programjaiba. A megújitást segíthetik a határon átnyúló egyưittmúkôdések fizikai rendszerének, mint például határátkelők (ideiglenes, vagy állandó) kiépitése, úthálózat és egyéb infrastruktúrák (pl. benzinkút, szervíz, szállásférőhely) kialakítása. Fontos szerephez kell jutnia a koordinált bilateriális (települési) kapcsolatoknak, mind a társadalom, mind a gazdaság szintjén, ezzel is hozzájárulva a gazdasági és társadalmi potenciájuk nôvekedéséhez.

\section{VIII. Átmeneti, vegyesgazdaságú térségek: \\ Fertỗ-mente, Kapuvár és térsége, Sokoróalja, Csepreg-Bük, Répcelak, Sárvár Körmend, Szentgotthárd, Zalalövő és Pápa térsége}

A fent hivatkozott ábrából is világosan kitünik, hogy ezek a térségek a gazdasági innovációval jellemzett térségekhez kapcsolódnak, rájuk füzödnek fel. Jellemzöjük, hogy az átmenet fejlődési stádiumában vannak. Kötődnek a gazdasági innováció terúleteihez, a régió centrumaihoz, gazdasági szerkezetük heterogén, szintén az átmenetet tükrözik, különösen a gazdasági aktivitás mértéke figyelemre méltó, s mindemellett a térség egészénél fejlettebb infrastruktúrát koncentrálnak. A pólusterületekhez még nem, az elmaradott, rurális, ipari válságtérség szerkezeti karakterủ térségekhez már nem sorolhatók, esetükben éppen ez jelenti az átmenetet. Úgy is mondhatnánk, hogy a lehetőségek térségei, hiszen felzárkózhatnak - éppen területi elhelyezkedésulk miatt - az innovációs területekhez, de könnyen leszakadhatnak a válságtérségek valamelyik típusába is.

Fejlesztésüknél az egyedi kezelésük kidolgozása szükséges, hiszen minden egyes térségre meghatározhatók azok a sajátosságok, amelyek fejlesztése a kedvezó folyamatot erősítheti. Az egyedi fejlesztési programok mellett fontos iránya a fejlesztésnek, hogy az interregionális kapcsolataik kiszélesedjenek, a centrumaik funkcióikban megerősődjenek, s minél több szálon integrálódjanak a régió nagyközpontjaihoz, akár úgy is, hogy bizonyos funkcióikat átvállaljanak, vagy azokat kiegészitsék. A régió fejlesztésének nagy tartalékát jelentik ezek a térségek, fejlesztésük különös figyelmet érdemel.

\subsection{Intézmény és eszközrendszer}

A területfejlesztésról és rendezésről szóló törvény (1996. XXI. törvény) szerint a megyehatárokon túlterjedő egyes terủletfejlesztési feladatok ellátására a megyei területfejlesztési tanácsok regionális fejlesztési tanácsot (RFT) hozhatnak létre. A terulletfejlesztési koncepció kidolgozását a regionális fejlesztési tanács végzi. Az általunk ôsszeállított régió fejlesztési stratégia alapja lehet, egy a jövőben megalakuló Északnyugat-dunántúli Regionális Fejlesztési Tanács által készítendő koncepciónak, azt egészében, vagy részben tartalmazhatja. 
A törvény szellemében a területfejlesztési koncepció az érintett megyékben lezajló széleskörü egyeztetés és jóváhagyás után indikatív (vagy kötelező érvényü) területfejlesztési dokumentummá válik, tehát csak az abban szereplö fejlesztési programok tarthatnak igényt a központi pénzalapok támogatásaira, illetve a területfejlesztés egyéb pénzügyi konstrukcióira.

A területfejlesztés sokszereplös rendszer, így szükséges a nagyobb térségi szintü, illetve több megyét érintó fejlesztéseket koordinálni, segítve az abban foglalt célok megvalósítását. Míg azonban a már megalakult megyei területfejlesztési tanácsok esetében nagyjából látható, hogy milyen pénzügyi eszközökkel rendelkeznek feladataik ellátásához, addíg erről az RFT esetében nem sokat tudunk. A törvény annyit jelez csupán számunkra, hogy az RFT rendelkezik a hatáskörébe utalt pénzeszközökröl, továbbá megállapodik a megyei területfejlesztési tanácsokkal és más, a térségi fejlesztési programokban közremüködökkel a programok és fejlesztések finanszírozásáról.

Mindezek figyelembevételével a területfejlesztési stratégia prioritásaihoz rendelt programok koordináló szervezetét meghatároztuk, de a partnerség elve alapján a megvalósításban résztvevö intézmények és azok lehetséges finanszírozási forrásait is megjelöltük (1-2. táblázat).

Maradnak az INTERREG II.- PHARE CBC program forrásai, ezek támogatásánál már lehet alkalmazni a stratégiába foglalt célokat és prioritásokat, illetve a területfejlesztés szereplői - állami, megyei és helyi alapok, non-profit szervezetek, valamint a gazdasági szereplök (vállalkozások, bankok, háztartások) - által rendelkezésre álló eszkőzöket, amelyek szintén korlátozottak. Ebben az esetben azonban törekedni kell arra, hogy a fejlesztési régiót egy egységként kezelve Veszprém megye is a program kedvezményezettjei közé tartozzék. 


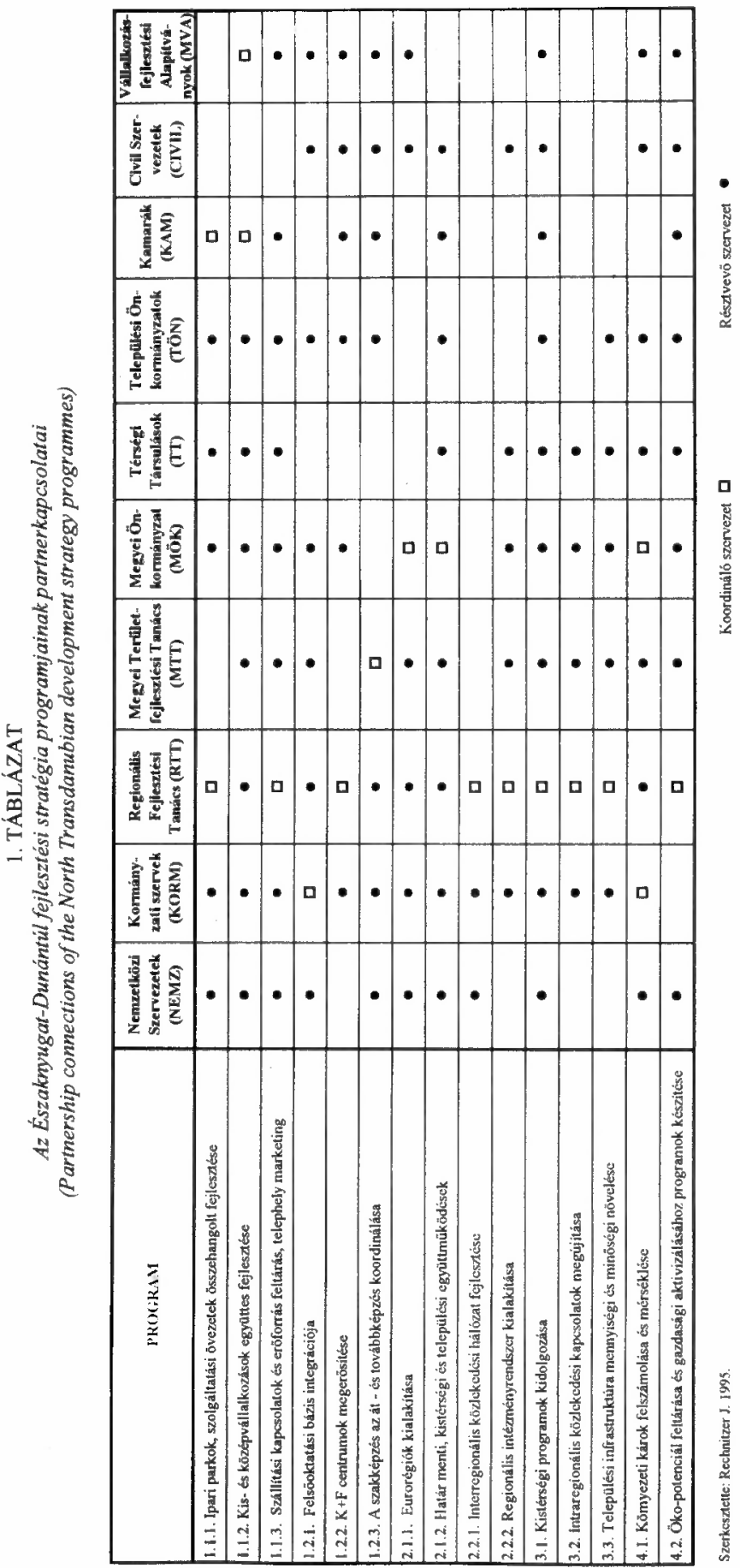




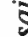

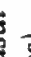

ปิ

:

ปั

ङ

$+2$

(2)

空

2

ह

$\frac{10}{2}$

dis

हे

我

$\infty$

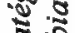

:

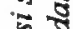

氙

v

क्ष.

곤

ฟ

\&

รี

s

今

ํํํ

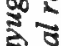

ह

造

구
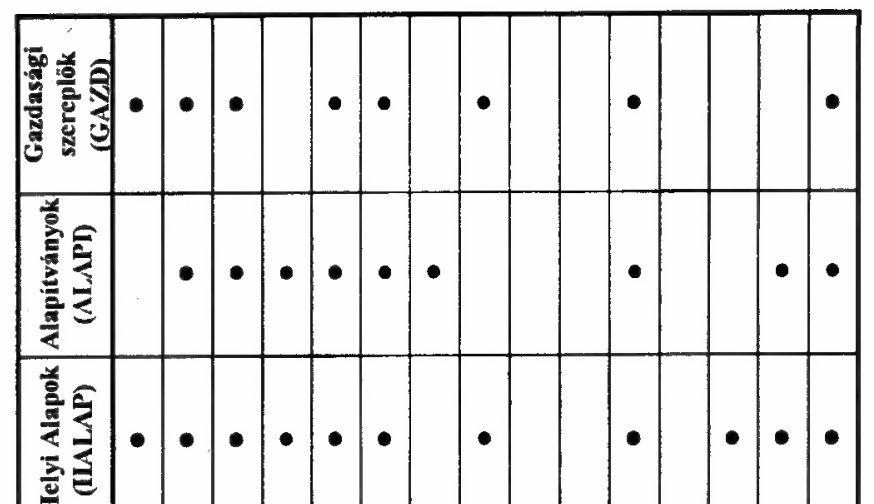

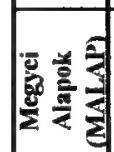

트릉

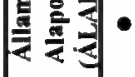

흘 을 올
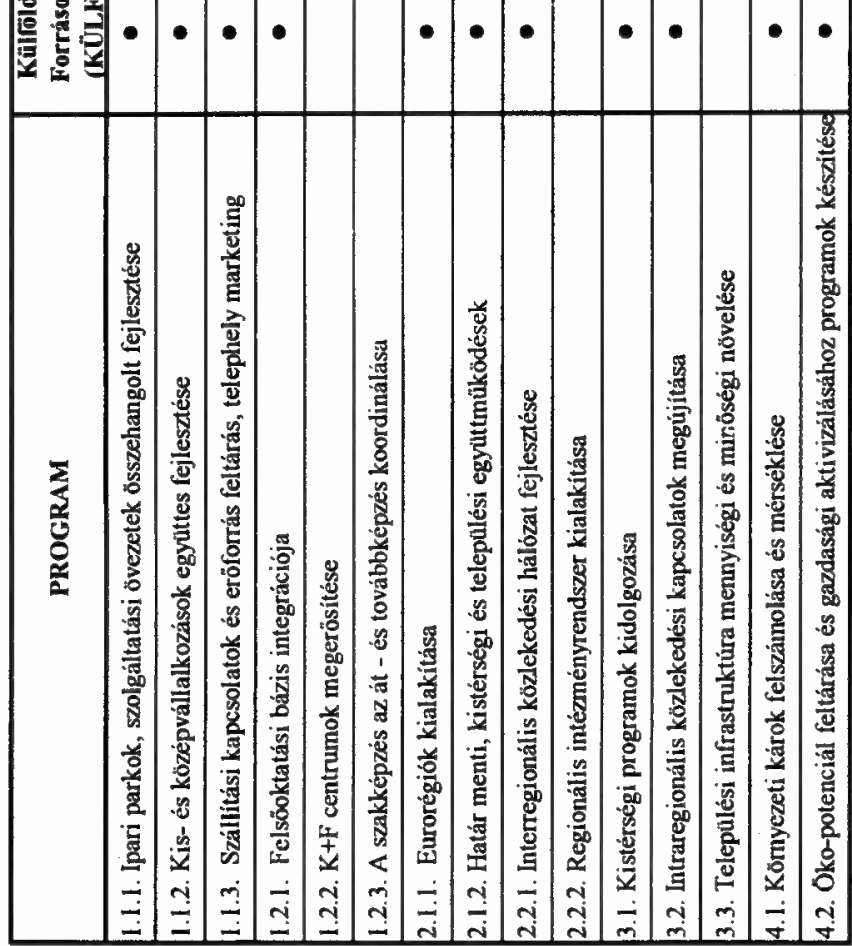

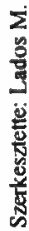




\section{Jegyzetek}

' A program elökészítő szakaszában (1995. január-március), mind a megbízó (KTM), mind az érintett megyék képviselói egyetértettek a koncepció által lehatárolt célterülettel. Az 1996. október-november folyamán - az Országos Teruletfejlesztési Koncepciónak az egyes megyei teruletfejlesztési tanácsoknál megrendezett megvitatása, valamint a megyei önkormányzati elnőkök személyes konzultációja során egyaránt - szóba kerult a régiószervezés kérdése. Az érdekelt megyék szorgalmazzák, hogy az OTK-ba egy ebböl a négy megyéböl képződő régió is keruljjön be a javasolt régió felosztási javaslat mellé. Napjainkban még viták folynak a régió területi lehatárolásáról.

${ }^{2}$ A megyei jovőképek magukba épitették a már elkészult kistérségi és városi stratégiákat. Ugyanakkor a megyei terulletfejlesztési tanácsok pályázati rendszere segitségével számos kistérségi fejlesztési program készul a közeljövőben. A régió és az egyes megyék fejlesztési koncepciójának elsö monitoringját éppen ezen most készulő programok beépítésének az igénye fogja meghatározni.

${ }^{3}$ A teruletfejlesztési koncepcióban tudatosan keralljük a régió szó használatát, az Északnyugat-Dunántúl esetében egy térségröl beszélunk, amelynek adottak a lehetöségei a regionális szervezödésre.

${ }^{4}$ Az Országos Teruletfejlesztési Koncepció már azzal számol, hogy a térségben az eddigi 14,5\%-os fejlesztési támogatás kihelyezést közép távon 12,5\%-ra csőkkenti, igényelve a térségi gazdaság és más szereplők nagyobb hozzájárulását a fejlesztésekhez.

${ }^{5}$ Az Országos teruletfejlesztési Koncepció már azzal számol, hogy a térségben az eddigi 14,5\%-0s fejlesztési támogatás kihelyezést kőzép távon 12,5\%-ra csőkkenti, igényelve a térségi gazdaság és más szereplök nagyobb hozzájárulását a fejlesztésekhez.

${ }^{6}$ A határgazdaság azt jelenti, hogy a térségek, települések speciális helyzetéböl következően a gazdasági faktorok több eleme felértékelö́dik. Részben a két ország az áraiban (valutáinak egymáshoz viszonyitott arányaiban) és a kínálatban meglévő különbségek miatt, részben pedig a fokozott kereslet kővetkeztében a telephelyi tényezök, de a jövedelmi és megélhetési viszonyok is eltérnek a tágabb térségben kialakult szinttỏl. A határgazdaság tehát speciális lokális piacot alakít ki, amely jóval rugalmasabb, nagyobb tơkekoncentrációt képvisel, mint a régió más terủletei, vagy más lokális piacai (pl. nagyvárosok, idegenforgalmi központok).

${ }^{7}$ A teruleti kutatásokban csak napjainkban kezdődik meg a várható EU-tagság következményeinek átgondolása, vélhetó, hogy a számos kedvezỏ - talán politikai szinten túldimenzionált - hatás mellett célszerủ számbavenni - föleg a fejlettebb térségekben - a kedvezötlen következményeket is.

8 Hegyeshalom-Györ-Tatabánya (-Budapest), Ajka-Veszprém-Várpalota (-Székesfehérvár-Budapest), Sopron-Szombathely-Körmend-Szentgotthárd, Balaton térsége.

${ }^{9}$ A térségben rövid távon a telefonhálózat és a kőzlekedési kapcsolatok alakítása a legszúkségesebb, míg hosszabb távon a szennyvizhálózat kiépítése és az energetikai rendszerek megújítása szäkséges a területi adottságok egyúttes figyelembevételével.

\section{REGIONAL DEVELOPMENT STRATEGY OF NORTH-WEST TRANSDANUBIA}

\section{MIHÁLY LADOS - JÁNOS RECHNITZER}

The study introduces the development strategy of a region comprising four counties. North-West Transdanubia is an active area of Hungarian modernisation, a region where the counties show significant differences in the level of their development. Using the method of strategy building, the essay considers the strengths and weaknesses of the region and looks at the possibilities and threats of development. The SWOT analysis reveals three scenarios for the future of the 
region. The first prospect of the future is a projection of the present situation, the second one considers a more moderate economic growth while the third one suggests a dynamic development. The authors state the mission of the region based on the second scenario. The mission of the regional developments is to promote the already started economic transitions and provide a suitable environment for them. The objectives of the development and their programme versions are also included in the study. Finally it defines the regions where intervention is necessary, pointing at their particular features and the development possibilities.

The development strategy was an experiment to find what principles and methods can be the basis on which the future prospects of a territory - which is not yet a functional region - can be worked out. 